Review

\title{
Geminivirus protein structure and function
}

\author{
VINCENT N. FONDONG * \\ Department of Biological Sciences, Delaware State University, 1200 North DuPont Highway, Dover, DE 19901, USA
}

\section{SUMMARY}

Geminiviruses are a family of plant viruses that cause economically important plant diseases worldwide. These viruses have circular single-stranded DNA genomes and four to eight genes that are expressed from both strands of the double-stranded DNA replicative intermediate. The transcription of these genes occurs under the control of two bidirectional promoters and one monodirectional promoter. The viral proteins function to facilitate virus replication, virus movement, the assembly of virus-specific nucleoprotein particles, vector transmission and to counteract plant host defence responses. Recent research findings have provided new insights into the structure and function of these proteins and have identified numerous host interacting partners. Most of the viral proteins have been shown to be multifunctional, participating in multiple events during the infection cycle and have, indeed, evolved coordinated interactions with host proteins to ensure a successful infection. Here, an up-to-date review of viral protein structure and function is presented, and some areas requiring further research are identified.

\section{INTRODUCTION}

Geminiviruses (family Geminiviridae) are among the most devastating plant pathogens worldwide and, together with potyviruses (family Potyviridae), constitute the two largest and most important plant virus families (Gibbs and Ohshima, 2010; Scholthof et al., 2011). By causing heavy losses on food and cash crops, such as cassava, tomatoes, grain legumes, vegetables, maize and cotton, geminiviruses represent a new threat to global food security and sustainability. During the last two decades, epidemics of re-emerging and newly emerging geminiviruses have caused huge crop losses and threatened crop production, particularly in the tropics and subtropics. Because of their agricultural importance, geminiviruses have been characterized extensively at the molecular level.

Geminivirus genomes consist of one (monopartite) or two (bipartite) circular single-stranded DNA (ssDNA) molecules, which are packaged in icosahedral twinned particles (Böttcher et al., 2004; Krupovic et al., 2009; Zhang W. et al., 2001). These viruses

*Correspondence: Email: vfondong@desu.edu are divided into four genera-Begomovirus, Curtovirus, Topocuvirus and Mastrevirus - based on genome organization, nucleotide sequence similarities and biological properties (Brown et al., 2012). Begomoviruses (type species Bean golden mosaic virus, BGMV) have either monopartite or bipartite genomes and are transmitted by whiteflies (Bemisia tabaci) (Brown, 1994). The two genomic components of bipartite begomoviruses are designated DNA-A and DNA-B (Fig. 1a). DNA-A has six open reading frames (ORFs), two in the virion sense (AV1 and AV2) and four in the complementary sense (AC1, AC2 and $A C 3$ and $A C 4)$. DNA-B has two ORFs, the virion-sense BV1 and complementary-sense BC1. The AV2 ORF is found in Old World bipartite begomoviruses, but not in New World viruses. Except for an approximately 200nucleotide segment of the $5^{\prime}$ intergenic region (IR), designated the common region $(C R)$, the two genomic components of bipartite begomoviruses are different in sequence. The CR contains an origin of replication organized modularly, including a stem-loop structure containing the invariant nonanucleotide TAATATTAC sequence, which is required for the cleavage and joining of the viral DNA during replication (Laufs et al., 1995). The ORFs of monopartite begomoviruses include the virion-sense $V 1$ and $V 2$ genes and the complementary-sense $C 1, C 2, C 3$ and $C 4$ genes (Fig. 1b).

Mastreviruses (type species Maize streak virus, MSV) are transmitted by leafhoppers (order Hemiptera, family Cicadellidae) and have a single genome component. Except for a recent identification of mastreviruses in sweet potato in Peru (Kreuze et al., 2009) and in dragonflies (suborder Anisoptera) in Puerto Rico (Rosario et al., 2013), these viruses have been found only in the Old World, where they infect a range of monocotyledonous plants (reviewed in Brown et al., 2012) and, from recent reports, dicotyledonous plants (Hadfield et al., 2012; Liu et al., 1999; Nahid et al., 2008). Mastreviruses have four ORFs, V1 and V2 on the virion-sense strand, and C1 and C2 on the complementary-sense strand, separated by two IRs on opposite sides of the genome, designated as large (LIR) and small (SIR) (Kammann et al., 1991) (Fig. 1C). The SIR contains termination and polyadenylation sequences for both the complementary-sense and virion-sense transcripts, and is probably the origin of replication of the complementary-sense strand (Hayes et al., 1988). For mastreviruses, but not for viruses of other genera, an approximately 80-nucleotide primer is present in the virion and specifically anneals to the SIR (Kammann et al., 1991; Shen and Hohn, 1991). 

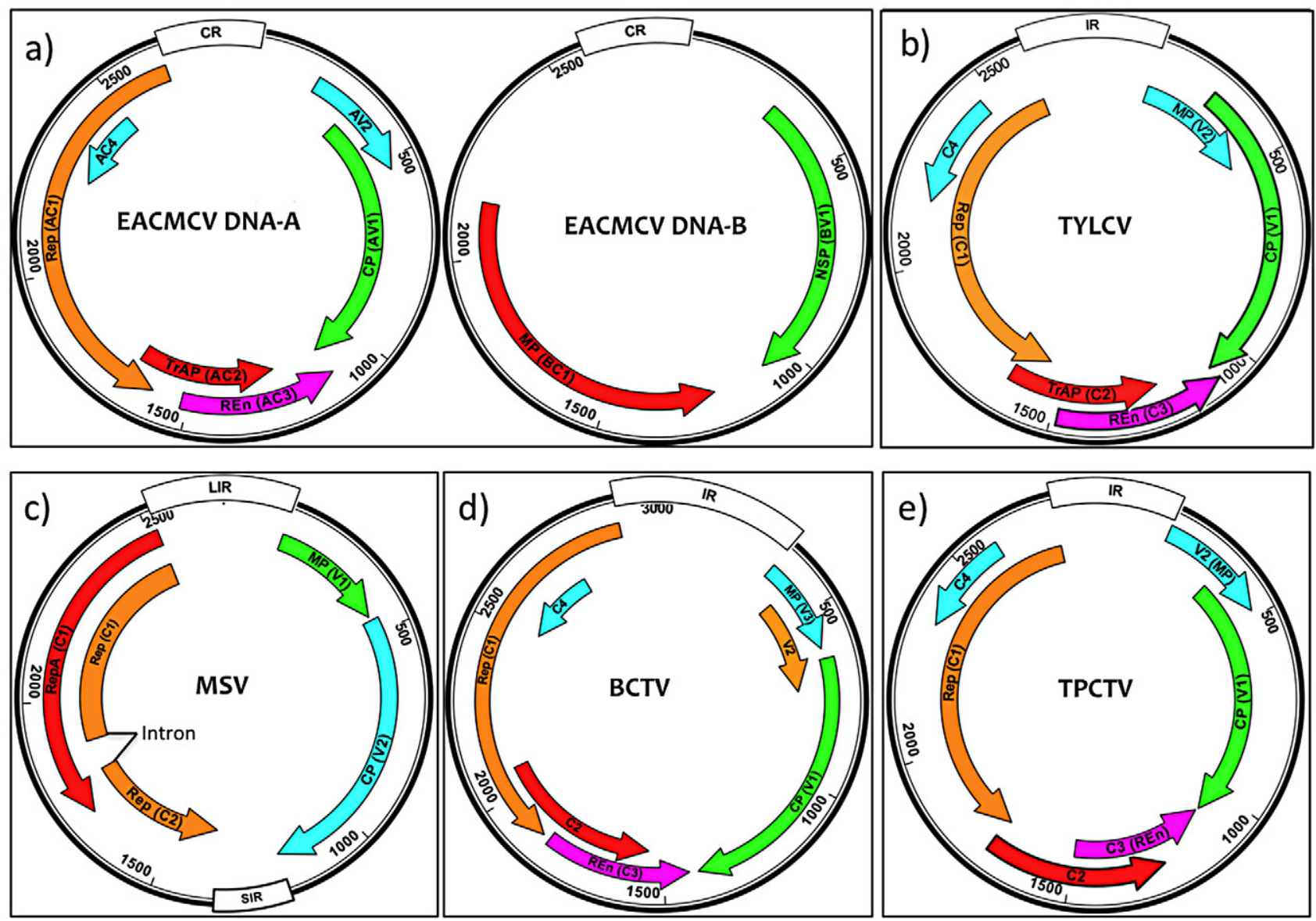

Fig. 1 Genome organization of representative members of the four geminivirus genera: Begomovirus, Mastrevirus, Curtovirus and Topocuvirus. Except for some begomoviruses, which have two component genomes, all geminiviruses have a single genome component. The bipartite begomovirus genome of a representative member, East African cassava mosaic Cameroon virus (EACMCV) (a) is composed of two DNA molecules, designated DNA-A and DNA-B, whereas Tomato yellow leaf curl virus (TYLCV) (b) is a single component genome begomovirus. Maize streak virus (MSV) (c) is a type member of mastreviruses, whereas Beet curly top virus (BCTV) (d) is the type member of curtoviruses and, so far, Tomato pseudo-curly top virus (TPCTV) is the only member of the genus Topocuvirus (e). Open reading frames (ORFs) are represented by curved arrows and are named according to the DNA component and the DNA strand on which they are found (viral sense, $V$ or complementary sense, C). Gene names are provided in the text. CP, coat protein; MP, movement protein; REn, replication enhancer protein; Rep, replicationassociated protein; TrAP, transcriptional activator protein.

Curtoviruses (type species Beet curly top virus, BCTV) infect dicotyledonous hosts, are transmitted by the beet leafhopper (Circulifer tenellus) and have monopartite genomes (Fig. 1d). The genome has seven ORFs and a single IR (Hormuzdi and Bisaro, 1995; Stanley et al., 1986). The three virion-sense ORFs are V1, V2 and V3. The four complementary-sense ORFs are C1, C2, C3 and C4. Like mastreviruses, curtovirus genomes contain a polyadenylation signal of approximately 20 nucleotides between the converging $\mathrm{V} 1$ and $\mathrm{C} 3$ ORFs.

The genus Topocuvirus, which so far has only one member, Tomato pseudo-curly top virus (TPCTV), has a monopartite genome and is transmitted to dicotyledonous hosts by treehoppers (Micrutalis malleifera) (Briddon et al., 1996). Topocuviruses have six ORFs (Fig. 1e): the virion-sense strand contains V1 and V2 and the complementary-sense strand contains $\mathrm{C} 1, \mathrm{C} 2, \mathrm{C} 3$ and $\mathrm{C} 4$, which are homologues of $\mathrm{AC} 1, \mathrm{AC} 2, \mathrm{AC} 3$ and $\mathrm{AC}$, respectively.

Previous comprehensive reviews (Gutierrez et al., 2004; Jeske, 2009; Stanley, 2004) have focused on the biological and molecular properties of geminiviruses. In this article, a review of current information on the molecular biology of geminiviruses and their satellites is provided, with special emphasis on viral protein structure, function and interactions with host proteins. Important areas needing additional research are also identified.

\section{REPLICATION-ASSOCIATED PROTEIN (AC1, C1)}

The replication-associated protein (Rep) encoded by the AC1 ORF (also called AL1) in bipartite geminiviruses and by C1 (also called L1) in monopartite geminiviruses (except mastreviruses) is 
a

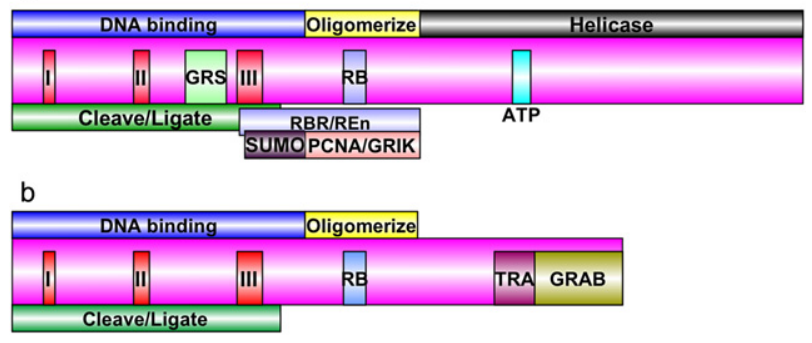

Fig. 2 The replication-associated protein (Rep) and replication-associated protein A (RepA) proteins. (a) The functional limits of the Rep domains for DNA cleavage/ligation are shown. DNA binding and protein interaction regions (characterized for begomoviruses and mastreviruses) are indicated. The DNA binding and cleavage/ligation domains contain the conserved motifs I (DNA binding), II (metal binding) and III (DNA cleavage and ligation) and the Geminivirus Rep Sequence (GRS). The N-terminal half of Rep also contains the oligomerization domain, and binding sites for the replication enhancer protein (REn), retinoblastoma-related protein (RBR), proliferating cell nuclear antigen (PCNA), GRIK, small ubiquitin-related modifier (SUMO)-conjugating enzyme (SUMO) and ATP. (b) The RepA C-terminus contains the binding sites for RBR and geminivirus RepA-binding (GRAB) transcription factors, as well as a promoter transactivation domain (TRA). It is important to note that, despite the sequence identity between Rep and RepA cleave/ligate and DNA binding domains, these domains have not yet been determined experimentally in RepA.

conserved in sequence, position and function (Hanley-Bowdoin et al., 2004) and is expressed under the control of a bidirectional core promoter in the IR (Hanley-Bowdoin et al., 1999). In the mastreviruses, the full-length Rep is translated from a spliced transcript of the C1 and C2 ORFs. The multifunctional nature of begomovirus Reps and the functional domains have been characterized (Heyraud-Nitschke et al., 1995; Orozco et al., 1997) (Fig. 2). Rep is essential for rolling circle replication (RCR) and is involved in the modulation of gene expression (Elmer et al., 1988; Etessami et al., 1991; Haley et al., 1992; Hong and Stanley, 1995; Saunders et al., 1991), analogous to some animal and bacterial ssDNA viruses (Stenger et al., 1991) and plasmids (Oshima et al., 2001), suggesting a strong evolutionary link between these proteins (llyina and Koonin, 1992).

The first step in geminivirus replication is the synthesis of the complementary strand from the genomic ssDNA using a stillunknown mechanism that is thought to be catalysed entirely by host factors. Rep, an early gene, confers virus-specific recognition of its cognate origin of replication (Fontes et al., 1994) and initiates DNA replication (Laufs et al., 1995; Lazarowitz et al., 1992; Orozco et al., 1997). The recognition mechanism appears to differ between mastreviruses and begomoviruses, based on the architecture of the origin of replication (Gutierrez et al., 2004). For mastreviruses, the origin consists of a large cis-acting region containing several Rep binding sites (Castellano et al., 1999; Sanz-Burgos and Gutiérrez, 1998), whereas the begomovirus origin contains a single Rep binding site (Fontes et al., 1992, 1994;
Lazarowitz et al., 1992; Orozco and Hanley-Bowdoin, 1998). In either case, however, the Rep oligomerizes into a complex as illustrated for MSV (Horvath et al., 1998), Wheat dwarf virus (WDV) (Castellano et al., 1999; Sanz-Burgos and Gutiérrez, 1998) and Tomato golden mosaic virus (TGMV) (Orozco and Hanley-Bowdoin, 1998) from mutational analyses of the oligomerization domain. In planta Rep oligomerization has been elucidated recently using Abutilon mosaic virus (AbMV) Rep bimolecular fluorescence complementation (BiFC) assay in Nicotiana benthamiana plants, where Rep oligomers accumulated in the nucleoplasm and replicated AbMV DNA-B (Krenz et al., 2011).

To initiate the RCR, the begomovirus Rep binds to the Rep complex binding site, which contains a directly repeated sequence between the TATA box and the transcription start site (Fontes et al., 1992). For the mastreviruses, the complex binds presumably to three sites located in the proximity of the two divergent TATA boxes upstream and downstream of the DNA replication initiation site and at the base of the conserved stem-loop (Castellano et al., 1999; Laufs et al., 1995). On binding, a process which involves motif I (Fig. 2a), the Rep complex cleaves the phosphodiester bond between the last $T$ and $A$ in the invariant loop sequence in a biochemical process mediated by motif II, which is a metal binding site that may be involved in protein conformation (Arguello-Astorga et al., 2004; Laufs et al., 1995; Orozco and Hanley-Bowdoin, 1998). A third sequence, motif III, is the catalytic site that is required for DNA cleavage and ligation (Orozco et al., 1997), thus providing the necessary $3^{\prime}-\mathrm{OH}$ for priming nascent viral DNA synthesis by host DNA polymerases. Recently, Nash et al. (2011) have identified a conserved motif, named the geminivirus Rep sequence (GRS) (Fig. 2a), and have shown that it is required for the initiation of virus replication. An artificial zincfinger protein designed to bind to the Tomato yellow leaf curl virus (TYLCV) Rep binding site with high affinity has been shown recently to inhibit Rep binding and TYLCV replication (Mori et al., 2012).

Several Rep-interacting proteins that are important in replication have been identified. Thus, a family of proteins involved in the negative regulation of the cell cycle related to retinoblastoma, designated retinoblastoma-related proteins (RBR), interacts with Reps of several geminiviruses (Ach et al., 1997; Kong et al., 2000; Xie et al., 1996). RBR represses cell cycle progression through its interactions with E2F (Arguello-Astorga et al., 2004). Accordingly, interaction between Rep and RBR interferes with the interaction between RBR and E2F and frees the activator class of E2F to activate the expression of genes required for DNA replication, including proliferating cell nuclear antigen (PCNA) (Arguello-Astorga et al., 2004; Egelkrout et al., 2001; Kong et al., 2000), which is permissive for viral DNA replication.

Also critical to viral DNA replication is the interaction between Rep and replication factor $C$ (RFC), which catalyses the loading of PCNA, a sliding clamp for DNA polymerase at the primer-template 
junction (Pavlov et al., 2004). Interaction between Rep and RFC is said to recruit RFC into the replication complex, where it facilitates the assembly of other replication factors (Luque et al., 2002). Rep also binds PCNA, which starts to accumulate in the G1 phase of the cell cycle, reaching the highest level during the $S$ phase and decreasing during the G2 and M phases (Gutierrez, 2000). Furthermore, TGMV Rep has been shown recently to interact with small ubiquitin-related modifier (SUMO)-conjugating enzyme (SCE1) to presumably modulate the SUMOylation level of host targets, thereby creating a suitable environment for virus replication (Castillo et al., 2004; Sánchez-Durán et al., 2011). Although SUMOylation plays an important role in human DNA virus infection by altering the molecular interactions of the modified substrate, changing the localization, stability and/or activity (reviewed in Wimmer et al., 2012), definitive conclusions on the role of SUMO modification during plant virus infection are yet to be determined.

Rep also interacts with the replication protein A (RPA) (Singh et al., 2007, 2008), a key protein in the recruitment of important proteins of the replication apparatus, such as DNA polymerase $\alpha$, RFC and PCNA (Loor et al., 1997). It is important to indicate that RPA is critical to other viral replication initiator proteins, including SV40 large T antigen (Weisshart et al., 1998), EBNA1 proteins of Epstein-Barr virus (Zhang et al., 1998), E1 proteins of papilloma virus (Loo and Melendy, 2004) and NS1 proteins of parvovirus (Christensen and Tattersall, 2002). Furthermore, Rep interacts with a kinesin-like motor protein (Kong and Hanley-Bowdoin, 2002) to presumably prevent cell cycle progression through $\mathrm{M}$ and favour the occurrence of endocycles (Desvoyes et al., 2006; Jordan et al., 2007), thus favouring viral DNA replication. We have also found that Rep interacts with $\beta$-tubulin6 (TUB6) (V. N. Fondong et al., unpublished data), suggesting that Rep movement may be microtubule dependent.

In addition to replication, some geminivirus Reps have been shown to be involved in viral gene regulation by repressing complementary-sense gene expression of mastreviruses (Collin et al., 1996; Hefferon et al., 2006) and begomoviruses (Eagle et al., 1994; Gröning et al., 1994; Haley et al., 1992; Shivaprasad et al., 2005), presumably after binding to Rep binding sites in the IR (Fontes et al., 1992; Frey et al., 2001). However, Rep appears not to repress virion-sense gene expression, as elucidated for Mungbean yellow mosaic virus (MYMV) Rep (Shivaprasad et al., 2005).

Together, these findings have contributed significantly to our understanding of the role of Rep in geminivirus replication and the mechanism of $R C R$; they have revealed the functional relationship between the geminivirus Rep and replication initiation proteins of other ssDNA viruses, as well as plasmids, and have supported the view that geminiviruses evolved from plasmids, even though, in a recent study based on sequence analysis, Saccardo et al. (2011) rejected the hypothesis that geminiviruses originated from plasmids of phytoplasma. However, still to be fully determined are the mechanism of cellular factor recruitment and the biochemical events leading to Rep binding to viral DNA to initiate genome replication. In addition, it is not yet known whether a ssDNA binding protein coats and stabilizes the geminivirus genomic ssDNA prior to replicative form synthesis, as has long been known for ssDNA phages that replicate via the RCR mechanism (Arai and Kornberg, 1979; Geider et al., 1978).

\section{REPLICATION-ASSOCIATED PROTEIN A (C1)}

The replication-associated protein $A(\operatorname{Rep} A)$, the protein product of ORF C1, and Rep are the two complementary-sense proteins of the mastreviruses (Collin et al., 1996; Gutierrez et al., 2004; Hofer et al., 1992; Liu et al., 1997), and are both required for virus replication. The RepA mRNA accounts for most of the complementary-sense transcripts in monocot-infecting mastreviruses, including MSV, WDV and Digitaria streak virus (DSV) (Dekker et al., 1991; Mullineaux et al., 1990; Wright et al., 1997), as well as in the dicot-infecting mastreviruses (Gutierrez, 2000; Hefferon et al., 2006; Munoz-Martin et al., 2003). RepA and Rep have identical primary sequences in their approximately $200 \mathrm{~N}$-terminal amino acid residues (Fig. 2b). Like Rep, RepA is multifunctional and, in several cases, performs the functions of bipartite geminivirus Reps, including the transactivation of virus-sense ORFs, as has been elucidated for MSV, WDV and Bean yellow dwarf virus (BeYDV) (Hefferon et al., 2006; Munoz-Martin et al., 2003). RepA also represses its own expression and the expression of Rep, as elucidated in BeYDV (Hefferon et al., 2006), by binding to a site in the LIR. RepA interaction with RBR has been mapped to the LXCXE motif in the mastreviruses MSV, BeYDV and WDV (Horvath et al., 1998; Liu et al., 1999; Xie et al., 1995). However, the LXCXE motif is absent in some mastrevirus RepAs, including Sugarcane streak virus (SSV), Miscanthus streak virus (MiSV) (Hughes et al., 1993) and BeYDV (Hefferon et al., 2006), suggesting that it is not an absolute requirement for mastreviruses. Furthermore, LXCXE is absent in begomovirus Reps, which bind to RBR through a novel, conserved $\alpha$-helical region (Arguello-Astorga et al., 2004; Hanley-Bowdoin et al., 2004; Kong et al., 2000). Other RepA interacting partners include a host transcription factor, designated GRAB (geminivirus RepA-binding), in the NAC family [acronym for NAM (for No Apical Meristem), ATAF1-2 and CUC2 (for CupShaped Cotyledon)] (Gutierrez et al., 2004; Xie et al., 1999). GRAB proteins, which are involved in plant development and senescence, impair geminivirus replication, suggesting that they modulate the viral replication cycle (Lozano-Duran et al., 2011; Xie et al., 1999).

Curiously, circoviruses, another group of circular ssDNA viruses, which infect animals and replicate using the RCR mechanism, also have two replication initiation proteins, designated Rep and Rep'. Rep and Rep' (a spliced isoform of Rep) are indispensable for circovirus replication (Mankertz and Hillenbrand, 2001) and have 
structural and functional similarities to Rep/RepA, suggesting a close evolutionary relationship between the two virus groups. However, whereas, in circoviruses, replication is terminated by a Rep/Rep'-catalysed nucleotidyl transfer reaction to cleave monomer units (Steinfeldt et al., 2006), geminivirus replication produces monomers and multimers, suggesting an inefficient Repmediated monomer cleavage during RCR.

\section{TRANSCRIPTIONAL ACTIVATOR PROTEIN (AC2, C2)}

The transcriptional activator protein (TrAP) is encoded by the AC2 (or AL2) ORF in bipartite begomoviruses and by $\mathrm{C} 2$ in monopartite begomoviruses. TrAP is a positional analogue of $\mathrm{C} 2$ (or L2) protein in curtoviruses and topocuviruses. $A C 2$, together with $A C 3$, is expressed from a dicistronic transcript driven by a strong monodirectional promoter located within the AC1 coding sequence (Shivaprasad et al., 2005). TrAP, which has been well characterized in begomoviruses, is a multifunctional protein. It is involved in gene activation (Haley et al., 1992; Shivaprasad et al., 2005; Sunter and Bisaro, 1992), virus pathogenicity (Hong et al., 1996) and suppression of gene silencing (Chowda-Reddy et al., 2009; Trinks et al., 2005; Vanitharani et al., 2005; Voinnet et al., 1999; Wang et al., 2005). TrAP activates the transcription of the genes coding for coat protein (CP) and movement protein (MP) in a non-virus-specific manner (Hanley-Bowdoin et al., 1999; Saunders and Stanley, 1995; Sunter et al., 1994), and transactivation is dependent on its zinc-finger and C-terminal acidic domains (Fig. 3) (Hartitz et al., 1999), as well as on its ability to form multimers (Yang et al., 2007). TrAP regulates the tissue-specific expression of the $\mathrm{CP}$ promoter by overriding a putative host repressor in phloem tissues (Sunter and Bisaro, 1997).

CP promoter modulation is thought to occur through TrAP interaction with different components of the cellular transcriptional machinery which binds the viral sequences required for the regulation of CP promoters (Lacatus and Sunter, 2009). The Arabidopsis transcription factor, PEAPOD2, specifically binds to activating sequences in the CP promoter of TGMV and Cabbage leaf curl virus (CaLCV) in mesophyll tissues, but not to sequences required for TrAP-mediated derepression in phloem tissues (Lacatus and

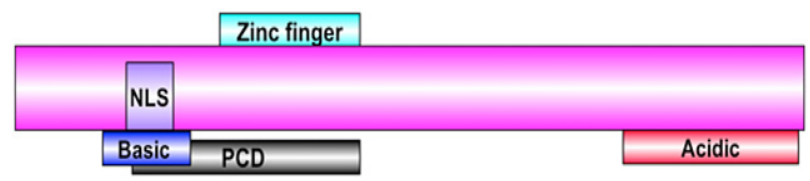

Fig. 3 The transcriptional activator protein (TrAP) and C2 proteins. The $\mathrm{N}$-terminal half of the geminivirus TrAP or C2 contains a nuclear localization signal (NLS) within a basic region and a central region contains a zinc finger-like motif and a domain that counters programmed cell death (PCD). The C-terminal end contains an acidic region required for transcriptional activation. The acidic domain is missing in curtovirus $\mathrm{C} 2$ proteins.
Sunter, 2009). TrAP does not specifically bind to double-stranded DNA (dsDNA) and, instead, is thought to be directed to responsive promoters through interactions with cellular proteins (Hartitz et al., 1999; Lacatus and Sunter, 2009). Thus, TrAP is similar to the Adenovirus E1A protein, a transactivational regulatory factor, which does not bind DNA, but is necessary for transcriptional activation (Avvakumov et al., 2002; Zu et al., 1992). Conclusive evidence of transcriptional activation activity by a monopartite begomovirus C2 protein was reported for Tomato leaf curl virus (ToLCV) (Dry et al., 2000), and it is likely that other monopartite begomovirus $\mathrm{C} 2$ proteins are also transcriptional activators. In contrast, the curtovirus C2 does not activate transcription (Hormuzdi and Bisaro, 1995). A possible mechanism of TrAP nuclear import for transcriptional activation is provided by the reported interaction between $\mathrm{C} 2$ of the begomovirus Bhendi yellow vein mosaic virus and karyopherin $\alpha$ (Chandran et al., 2012), a soluble receptor, which probably transports C2 through nuclear pore complexes into the nucleoplasm.

TrAP is also a pathogenicity factor, and may counter a hypersensitive response (HR) in infected cells. The HR, a form of programmed cell death (PCD) associated with resistance to pathogens, is induced at infected sites or within defined areas surrounding the infected sites and limits pathogen growth (a review is provided in Postel and Kemmerling, 2009 and in Coll et al., 2011). However, the TrAP of the bipartite begomovirus Tomato leaf curl New Delhi virus (ToLCNDV) can overcome nuclear shuttle protein (NSP)-induced HR (discussed below) (Hussain et al., 2007). TrAP compromises the ability of COP9 signalosome (CSN), a protein complex that functions in the ubiquitinproteasome pathway, to bind to Cullin-1 (CUL1), which is an essential component of the SCF (SKP1, CUL1/CDC53, F box proteins) ubiquitin E3 ligase complex. TrAP-COP9 interaction alters the cellular processes regulated by SCF complexes, including jasmonate signalling (Lozano-Duran et al., 2011), thereby regulating host response to infection.

Most plant viruses contain suppressors of RNA silencing, a phenomenon that regulates gene expression and protects plants from transposable elements and viruses (reviews are available in Pantaleo, 2011 and in Wang et al., 2012). The bipartite geminivirus TrAP and C2 from monopartite geminiviruses have been shown to suppress RNA silencing (Chowda-Reddy et al., 2009; Dong et al., 2003; Hamilton et al., 2002; Trinks et al., 2005; Vanitharani et al., 2004; Voinnet et al., 1999; Wang et al., 2005). Correspondingly, Beet severe curly top virus (BSCTV) C2 has been shown to decrease DNA methylation, thus affecting the production of small interfering RNAs (siRNAs) which are required for the targeting and reinforcing of RNA-directed DNA methylation and RNA silencing (Yang L.P. et al., 2012). Consistent with these findings, the transient expression of TGMV TrAP and BCTV C2 increases the susceptibility of tobacco to these geminiviruses (Hao et al., 2003; Sunter et al., 2001). 


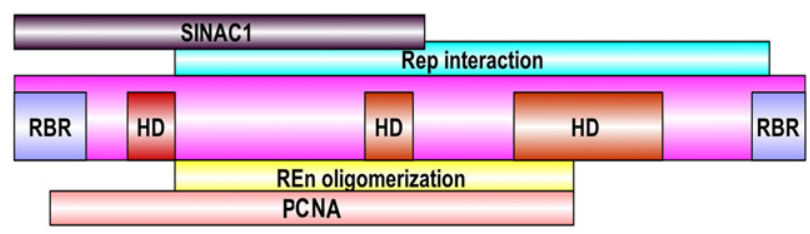

Fig. 4 The replication enhancer protein (REn). Several REn functional regions were elucidated on the basis of Tomato golden mosaic virus (TGMV), Tomato yellow leaf curl virus (TYLCV) and Tomato yellow leaf curl Sardinia virus (TYLCSV). Two retinoblastoma-related protein (RBR) interacting domains are located in both the N- and C-terminal ends. Three hydrophobic clusters (HD), an oligomerization, Rep as well as proliferating cell nuclear antigen (PCNA) and SINAC1 (Solanum lycopersicum NAC1) binding domains have been identified in REn.

Taken together, these findings establish the involvement of TrAP and $C 2$ in gene regulation and virus pathogenicity, and emphasize the multifunctional nature of geminivirus proteins, which, together with overlapping genes, contribute to viral genetic economy.

\section{REPLICATION ENHANCER PROTEIN (AC3, C3)}

The replication enhancer protein (REn), which is absent in mastreviruses, is encoded by the AC3 (or AL3) ORF in bipartite begomoviruses and by the C3 (or L3) ORF in curtoviruses and monopartite begomoviruses. Like $\mathrm{AC2}, \mathrm{AC} 3$ expression is driven by a strong monodirectional promoter located within the AC1 coding sequence (Shivaprasad et al., 2005). Although not essential for virus replication, REn enhances viral DNA accumulation and symptom development in plants infected by begomoviruses (Sung and Coutts, 1995; Sunter et al., 1990) and curtoviruses (Stanley et al., 1992). The role of REn in viral DNA replication involves its interactions with Rep and PCNA. Regions of REn responsible for these interactions were elucidated in two bipartite begomoviruses, TYLCV and Tomato yellow leaf curl Sardinia virus (TYLCSV) (Castillo et al., 2003; Settlage et al., 2005) (Fig. 4). Like Rep, REn does not contain an LXCXE motif, which mediates the binding of several mastrevirus RepAs to RBR, suggesting the existence of an alternative RBR interaction domain in REn (Settlage et al., 2001).

Like RepA, REn also interacts with SINAC1 (Solanum lycopersicum NAC1) (Selth et al., 2005). SINAC1 levels were shown to be higher in ToLCV-infected cells, suggesting that NAC1 is involved in viral DNA replication (Selth et al., 2005), possibly through an interaction with REn. Recently, the Tomato leaf curl Kerala virus REn was shown to interact with Rep and enhance the Repmediated ATPase activity (Pasumarthy et al., 2010), thus confirming a role for REn in viral DNA replication.

\section{AC4 PROTEIN}

The ORFs AC4 (or AL4) in bipartite geminiviruses and C4 (or L4) in monopartite geminiviruses (except mastreviruses, where $C 4$ is absent) are contained entirely within the AC1 ORF, but in a different frame, and are the least conserved of all geminivirus proteins, with divergent biological functions in monopartite and bipartite geminiviruses. Disruption of the C4 ORF of ToLCV (Rigden et al., 1994), TYLCV (Jupin et al., 1994) and BSCTV (Teng et al., 2010) caused a reduction in viral DNA levels and symptom development, suggesting its involvement in symptom development and virus movement. C4 is also the major determinant of the characteristic vein swelling phenotype observed in plants infected by BCTV (Mills-Lujan and Deom, 2010; Stanley and Latham, 1992; Stanley et al., 1986). Expression of the BCTV and BSCTV C4 proteins in transgenic Arabidopsis results in phenotypes that mimic the symptoms seen during viral infection (Mills-Lujan and Deom, 2010). Similarly, the expression of BCTV C4 in transgenic $N$. benthamiana results in ectopic cell division (Latham et al., 1997; Piroux et al., 2007), implying that the vein swelling associated with BCTV C4 is caused by abnormal cell division. Consistent with this finding, Lai et al. (2009) reported that BSCTV C4 induced the expression of RKP, which may be involved in cell cycle regulation. According to a study by Park et al. (2011), infection by BSCTV, as well as overexpression of BSCTV C4, leads to the induction of expression of ATHB7 and ATHB12 in Arabidopsis thaliana. These observations implicate C4 in infected cell development and differentiation.

TGMV AC4 has been reported to be involved in virus movement (Pooma and Petty, 1996), but is not critical for virus infection (Elmer et al., 1988), and disruption of the AC4 ORF in African cassava mosaic virus (ACMV) and East African cassava mosaic Zanzibar virus (EACMZV) has no effect on the infection phenotype in N. benthamiana (Bull et al., 2007; Etessami et al., 1991). Similar observations were reported for AC4 encoded by BGMV (Hoogstraten et al., 1996) and Potato yellow mosaic virus (Sung and Coutts, 1995).

The ability of AC4 and C4 to suppress RNA silencing is conserved for several bipartite and monopartite geminiviruses. For example, AC4 proteins of ACMV and East African cassava mosaic virus (EACMV)-like viruses have been shown to suppress RNA silencing (Fondong et al., 2007; Vanitharani et al., 2004) by binding microRNAs (miRNAs) and siRNAs (Chellappan et al., 2004). The ability of East African cassava mosaic Zanzibar virus (EACMZV) AC4 to suppress silencing depends on its N-terminal myristoylation sequence, in which acetylation occurs as a result of the attachment of a myristate and a palmitate in the $\mathrm{N}$-terminus (Fondong et al., 2007). Furthermore, ToLCV-Au C4 suppresses silencing by binding to shaggy-like kinase (SISK) through its C-terminus (Dogra et al., 2009).

\section{COAT PROTEIN (AV1, V1)}

The geminivirus CP is a late gene and is the only structural protein of geminivirus particles (Stanley and Gay, 1983). It is encoded by 
the AV1 (also AR1) ORF in bipartite geminiviruses and by the V1 ORF in monopartite geminiviruses (Zhang W. et al., 2001). In addition to virus genome packaging, the CP has been associated with several other functions, including insect transmission (Boulton et al., 1993; Briddon et al., 1990; Mullineaux et al., 1984), shuttling of viral DNA into and out of the nucleus in monopartite geminiviruses (Liu et al., 1999), and cell-to-cell and systemic spread of virus (Boulton et al., 1989; Liu et al., 1997; Pitaksutheepong, 1999). The CP binds ss- and dsDNA (Liu et al., 1997) and may participate indirectly in viral DNA replication during RCR by binding and sequestering SSDNA from the replication cycle (Saunders et al., 1991; Stenger et al., 1991). Although all begomovirus CPs contain sequences that are highly conserved, they also contain regions that are variable and can be used to correlate phylogenetic inferences with biotic and geographic characteristics (Padidam et al., 1995). Evidence that the CP plays a critical role in insect virus transmission was elucidated using the whitefly-transmitted ACMV and the leafhopper-transmitted BCTV. An ACMV chimeric virus containing the BCTV CP gene is transmitted by leafhoppers, which, in nature, transmit BCTV but not ACMV (Briddon et al., 1990). Sequences important for insect transmission have been mapped to the central part of CP (Hohnle et al., 2001; Kheyr-Pour et al., 2000; Liu et al., 2001; Noris et al., 1998; Unseld et al., 2001) and may play a role in CP multimerization, which is necessary for virus capsid assembly and insect transmission (Hallan and Gafni, 2001; Noris et al., 1998; Zhang W. et al., 2001).

Some monopartite geminivirus CPs shuttle viral DNA between the nucleus and the cytoplasm, as has been elucidated for mastreviruses (Liu et al., 1999, 2001) and for TYLCV (Kunik et al., 1998; Rojas et al., 2001). This is consistent with the fact that the CP of Squash leaf curl virus (SqLCV), a bipartite begomovirus, can functionally replace NSP (encoded by BV1) (Ingham et al., 1995; Qin et al., 1998). Nuclear import and export appear to be dependent on SsDNA binding to the $\mathrm{N}$-terminal domain of the $\mathrm{CP}$ (Pitaksutheepong et al., 2007). The CP nuclear localization signal (NLS) has been localized to the $\mathrm{N}$ - and C-termini and the central region of the protein (Unseld et al., 2001) (Fig. 5). The bipartite begomovirus MYMV CP interacts with importin $\alpha$, a component of the nuclear pore-targeting complex (Guerra-Peraza et al., 2005), and the N-terminal NLS of TYLCV CP binds to karyopherin $\alpha 1$ (Kunik et al., 1999) for nucleocytoplasmic trafficking. The

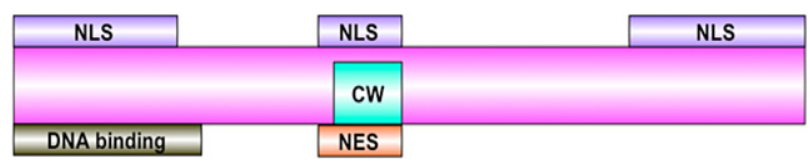

Fig. 5 The coat protein (CP) contains three nuclear localization signal (NLS) motifs, the N-terminal domain overlapping with the DNA binding domain. The central NLS is in the same region as the nuclear export signal (NES) and the cell wall targeting motif (CW).
N-terminal NLS also binds to the GroEL protein of Arsenophonus, a bacterial endosymbiont found in the midgut of Bemisia tabaci, presumably to protect the virions in the insect vector haemolymph (Kunik et al., 1999; Morin et al., 2000; Rana et al., 2012; Yaakov et al., 2011). A leucine-rich nuclear export signal (NES) that mediates trafficking from the nucleus to the cytoplasm was mapped to the CP central region (Ward and Lazarowitz, 1999). It is important to note that bipartite begomoviruses with mutated or replaced CP are infectious, albeit with delayed and attenuated symptoms (Brough et al., 1988; Pooma et al., 1996; Sudarshana et al., 1998), suggesting that other host proteins functionally replace the $C P$ and import the genome to the nucleus on initial viral infection and prior to the synthesis of NSP.

Interestingly, geminivirus CPs accumulate preferentially in the nucleolus, as exemplified by CPs of the monopartite begomoviruses Tomato leaf curl Java virus (ToLCJV) (Sharma and Ikegami, 2010) and TYLCV (Rojas et al., 2001), and the bipartite begomovirus EACMCV (V. N. Fondong et al., unpublished data). It is worth noting that increasing numbers of key proteins from both animal RNA and DNA viruses have been shown to localize to the nucleolus and to play important roles in the virus infection cycle, including herpesvirus saimiri ORF57 protein (Boyne and Whitehouse, 2006), coronavirus protein N (Hiscox et al., 2001), Groundnut rosette virus ORF3 (Kim et al., 2007a), Potato leaf roll virus CP (Kim et al., 2007a) and Potato mop top virus triple gene block 1 protein (TGB1) (Kim et al., 2007b). These observations implicate the nucleolus in the virus infection cycle. Indeed, it has been shown recently that nucleolar localization is required for Alfalfa mosaic virus virion formation and systemic movement (Herranz et al., 2012).

In addition to nuclear shuttling, CPs of mastreviruses (Liu et al., 2001) and monopartite begomoviruses (Briddon et al., 1989; Padidam et al., 1996; Rigden et al., 1993) are involved in cell-to-cell movement and systemic spread of viral DNA. Movement is effected presumably through interaction with the MP (V2 ORF), as demonstrated for TYLCV (Poornima et al., 2011) and Cotton leaf curl Kokhran virus (Poornima et al., 2011). Although bipartite begomovirus CPs may not be required for infection, they have been shown to enhance cell-to-cell and/or systemic spread of several viruses, including SqLCV (Ingham et al., 1995), ACMV (Stanley and Townsend, 1986), Bean dwarf mosaic virus (BDMV) (Seo et al., 2004), Pepper huasteco virus (Guevara-González et al., 1999), BGMV (Pooma et al., 1996), CaLCV (Carvalho et al., 2008b) and TGMV (Gillette et al., 1998; Pooma et al., 1996). These observations suggest that the bipartite begomovirus CPs have not lost these functions during evolution from their monopartite progenitors.

Although not essential in virus replication, the absence of CPS results in reduced levels of viral ssDNA with or without a reduction in the level of dsDNA of TYLCV (Padidam et al., 1996), TGMV (Brough et al., 1988; Sunter et al., 1990), BCTV (Briddon et al., 
1989), ToLCNDV (Padidam et al., 1999), SqLCV (Qin et al., 1998) and BeYDV (Hefferon and Dugdale, 2003).

Together, these findings provide further evidence that the evolution of multifunctional proteins compensates for small-genome viruses and that multifunctional proteins highlight the plasticity through which evolution brings together functional domains into a single polypeptide chain (Walsh and Mohr, 2006).

\section{AV 2 PROTEIN}

The AV2 ORF (V2 in monopartite geminiviruses), whose start codon precedes that of the AV1 ORF, is found in 'Old World', but not in 'New World', bipartite begomoviruses (Bull et al., 2007; Padidam et al., 1996; Rojas et al., 2001; Selth et al., 2004), and its exact function is uncertain. Although ACMV clones containing mutations in AV2 are infectious in N. benthamiana (Etessami et al., 1989), recent findings showing that Mungbean yellow mosaic India virus (MYMIV) clones containing mutations in AV2 reverted to wild-type (Rouhibakhsh et al., 2011) raise the possibility that the progeny from mutant ACMV clones might have reverted to wild-type, thereby masking the effect of the mutation. This is supported by evidence that ToLCNDV containing mutations in AV2 accumulates low levels of viral DNA in infected plant tissues (Padidam et al., 1996). Correspondingly, V2 ORFs of the monopartite begomovirus TYLCV (Wartig et al., 1997) and the curtovirus BCTV (Hormuzdi and Bisaro, 1995; Stanley et al., 1992) appear to be pathogenicity determinants, and mastrevirus and monopartite begomovirus V2 ORFs encode MPs, as discussed in the section on Movement proteins below.

Plants infected with ToLCV and ToLCNDV containing mutations in V2 and AV2, respectively, resulted in low levels of mutant viral DNA in infected plant tissues (Padidam et al., 1996; Rigden et al., 1993; Selth et al., 2004). Similar results have been reported recently for Papaya leaf curl virus and Cotton leaf curl Kokhran virus (Mubin et al., 2010). These findings were subsequently supported by studies showing that both AV2 and V2 suppress RNA silencing, as illustrated for EACMCV AV2 (Chowda-Reddy et al., 2008) and V2 of the monopartite begomovirus Ageratum yellow vein virus (Sharma and Ikegami, 2010; Sharma et al., 2010). Similar observations have been made for TYLCV V2, most probably as a result of its interaction with the suppressor of gene silencing3 protein (SGS3) (Glick et al., 2008).

\section{NUCLEAR SHUTTLE PROTEIN (BV1)}

BV1 (also BR1) is one of the two ORFs found in the B component of bipartite begomoviruses. BV1 encodes the NSP (Fig. 6) required for trafficking viral ssDNA between the nucleus and the cytoplasm (Noueiry et al., 1994) in the form of a viral DNA-NSP complex (Ward and Lazarowitz, 1999). Evidence that NSP binds to DNA in a sequence non-specific manner has been illustrated for SqLCV

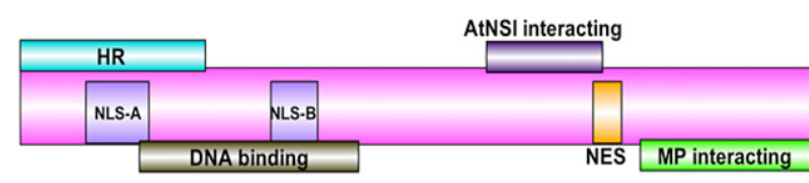

Fig. 6 The nuclear shuttle protein (NSP). The NSP N-terminal half contains two nuclear localization signals (NLS-A and NLS-B), DNA binding and sequences required for the induction of the hypersensitive response, whereas the NSP C-terminus contains the nuclear export signal (NES), movement protein (MP) binding site and the Arabidopsis nuclear shuttle protein interactor (AtNSI).

(Pascal et al., 1994), BDMV (Rojas et al., 1998) and AbMV (Hehnle et al., 2004). To achieve cell-to-cell and long-distance movement, the NSP-viral DNA complex is trapped by the MP in the cytoplasm and redirected to and across the cell wall into adjacent cells, where NSP directs the viral genome to the nucleus for new cycles of replication (Lazarowitz and Beachy, 1999; Noueiry et al., 1994; Sanderfoot and Lazarowitz, 1995; Sanderfoot et al., 1996; Ward et al., 1997). It is important to note that NSP is consistently being shown not to be required for virus infectivity, presumably because the CP exhibits nuclear import and export functions as discussed above. This has led to the suggestion that both proteins have a common evolutionary origin and share redundant functions (Zhou et al., 2007), including the nucleocytoplasmic transport of viral DNA (Liu et al., 1997; Rigden et al., 1993; Saeed et al., 2007). Accordingly, both proteins localize in the nucleus, preferentially to the nucleolus (Fig. 6) (Rojas et al., 2001; Sharma and Ikegami, 2009; Zhou et al., 2011).

The mechanism by which NSP shuttles viral DNA between the nucleus and the cytoplasm has been elucidated using CaLCV NSP, which interacts with an Arabidopsis protein, nuclear shuttle protein interactor (AtNSI) (McGarry et al., 2003). This interaction presumably results in the acetylation of NSP and the segregation of ssDNA for movement and encapsidation. Several geminivirus NSPs are also known to interact with a cytoplasmic GTPase to export the viral DNA-NSP complex from the nucleus to the cytoplasm, where it is redirected to the cell surface to interact with the viral MP (Carvalho et al., 2008a). Evidence from SqLCV NSP shows that the nuclear export of nascent viral DNA from the nucleus to the cytoplasm is mediated by a leucine-rich NES.

In addition to virus trafficking, NSP is an avirulence determinant in some hosts. Thus, BDMV NSP has been reported to induce an HR in Phaseolus vulgaris (Garrido-Ramirez et al., 2000; Zhou et al., 2007), as does ToLCNDV NSP in N. tabacum and tomato (Solanum lycopersicum) (Hussain et al., 2005, 2007). The involvement of NSP in virus pathogenicity is supported by its interactions with membrane receptor kinases, including NSP-interacting kinase (NIK), belonging to the receptor-like group of kinases implicated in a wide range of signal transduction pathways (Fontes et al., 2004; Rocha et al., 2008; Sakamoto et al., 2012; Santos et al., 2009). NSP also interacts with proline-rich extensin-like receptor protein 
kinase (PERK), probably to phosphorylate and regulate NSP function (Florentino et al., 2006; Fontes et al., 2004). Furthermore, a recent study has shown that a host nucleoprotein, histone H3, interacts with BDMV NSP and MP, forming a complex of histone H3, NSP, MP and viral DNA (Zhou et al., 2011), to presumably facilitate the export of nascent viral DNA from the nucleus to the cytoplasm for cell-to-cell and long-distance movement.

\section{MOVEMENT PROTEIN (BC1, V2)}

The MP is encoded by the BC1 (or BL1) ORF on the DNA-B components of bipartite begomoviruses. In monopartite begomoviruses, it is encoded by the V2 ORF, which has no sequence identity with BV1. The MP is required for virus cell-to-cell and long-distance movement, through its cooperative interaction with the NSP in bipartite begomoviruses (Noueiry et al., 1994; Ward et al., 1997). Recent data have suggested that MP-NSP cooperation, leading to nascent viral DNA export from the nucleus, follows a 'couple-skating' transport model (Frischmuth et al., 2007; Hehnle et al., 2004; Zhang S.C. et al., 2001), in which MP binds to NSP-DNA complexes at the cytoplasmic face of plasma membranes or microsomal vesicles and enables transfer to adjacent cells (Kleinow et al., 2009). The central region of MP is required for the formation of the MP-DNA-NSP complex (Fig. 7) (Frischmuth et al., 2007; Sanderfoot and Lazarowitz, 1995; Zhang et al., 2002). Unlike NSP, some geminivirus MPs do not appear to bind to DNA, as elucidated for MPs of SqLCV (Pascal et al., 1994) and AbMV (Hehnle et al., 2004). In contrast, MPs of BDMV (Rojas et al., 1998) and MYMIV (Radhakrishnan et al., 2008) bind both ss- and dsDNA with high affinity.

In monopartite begomoviruses and mastreviruses, the MP is encoded by the V2 ORF (Boulton et al., 1989, 1993; Mullineaux et al., 1988; Wartig et al., 1997), whereas CP (encoded by V1) shuttles viral DNA between the nucleus and cytoplasm, functionally replacing NSP. Although the monopartite geminivirus CP is required for viral movement (Boulton et al., 1989), V1 and V2 share no significant sequence identity with BC1 or BV1 (Rojas et al., 2001). Furthermore, there are functional differences between monopartite begomovirus MPs and MPs of mastreviruses. For instance, similar to bipartite begomovirus MPs, monopartite begomovirus MPs bind viral DNA, whereas mastrevirus

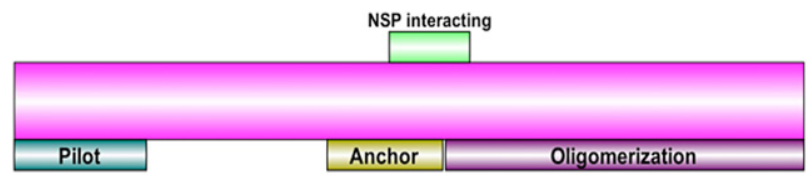

Fig. 7 The movement protein (MP). The BC1 encoded MP contains a pilot domain required for localization to the cell periphery, a central anchor domain that also targets the protein to the cell periphery and a C-terminal domain that facilitates oligomerization. The nuclear shuttle protein (NSP) binding site is in the centre of MP.
MPs do not. Furthermore, cell-to-cell movement in monopartite begomoviruses is mediated by C4 (Krichevsky et al., 2006; Rojas et al., 1998, 2001); CP, MP and C4 are involved in the delivery of TYLCV DNA, as virions or as nucleoprotein complexes, to the plant cell periphery (Rojas et al., 2001). To move the complex from the cell periphery for cell-to-cell transport, MP interacts with plasmodesmata (Rojas et al., 2001) and, because mastrevirus MPs do not bind viral DNA, virus movement is effected through interaction with the CP (Kotlitzky et al., 2000; Liu et al., 2001). Monopartite geminivirus MPs presumably enhance CP-mediated nuclear export of viral DNA and a NES was mapped to the N-terminus of ToLCJV V2 (Sharma and Ikegami, 2010). A model has been proposed, whereby MP diverts the CP-DNA complex from the nucleus to the cell periphery, where it mediates movement through the PD (Liu et al., 2001).

Curtovirus movement has been much less studied compared with that of other geminiviruses. A genetic analysis of BCTV genes showed that the V3 ORF encodes the MP (Hormuzdi and Bisaro, 1995), which forms vesicle-like structures that co-localize with the endoplasmic reticulum (ER) and are trafficked intracellularly from the nucleus to the cell periphery (Soto, 2001). The significance of these vesicles remains to be established.

The ER appears to play important, but differential, roles in MP intracellular trafficking. For instance, the MP of AbMV, a phloemlimited virus, exploits the cellular membrane flow from the ER to the plasma membrane (Zhang et al., 2002). Conversely, in virusinfected pumpkin sink leaves, MPs of SqLCV (a phloem-limited virus) and CaLCV (which infects all cell types) predominantly associate with ER-derived tubules that penetrate the cell wall and are found only in undifferentiated vascular tissues (procambium) and in lesser amounts within the plasma membrane (Ward et al., 1997). Furthermore, microtubules appear to play a role in MP-viral genome movement, as has been shown for Euphorbia mosaic virus (Kim and Lee, 1992) and Indian cassava mosaic virus (Roberts, 1989). In these cases, the MP-containing tubules appear to serve as conduits for the intercellular transport of viral complexes.

Several host proteins that interact with geminivirus MPs have been identified, including an Arabidopsis regulator of endocytosis, synaptotagmin (SYTA), which interacts with CaLCV MP at the plasma membrane and directs the MP onto early endosomes (Lewis and Lazarowitz, 2010). These endosomes are thought to traffic the complex via a recapture pathway to dock at the PD for intercellular transport. A similar interaction occurs between SYTA and the MP of Tobacco mosaic virus, an RNA virus, suggesting a convergent evolutionary lineage between these MPs, as there is no evidence that they share a common ancestry. Synaptotagmins are calcium sensors, and their ability to regulate synaptic vesicle exo-/endocytosis has long been characterized in animals (Fukuda, 2003) and, more recently, in plants (Chapman, 2008). Recently, AbMV MP has been reported to form a complex with the heat 
shock cognate 70-kDa protein to facilitate viral movement along cellular plastids and stromules into a neighbouring cell (Krenz et al., 2010, 2012). These data suggest that geminivirus movement may be tubule guided and non-tubule guided.

It is clear from these findings that geminiviruses, unlike most other virus groups, use different mechanisms to move within and between cells.

\section{GEMINIVIRUS SATELLITE REP AND BC1 PROTEINS}

There have been an increasing number of reports of monopartite begomoviruses occurring in association with circular SSDNA satellites, referred to as alphasatellites (Briddon et al., 2004; Paprotka et al., 2010; Romay et al., 2010) and betasatellites (Briddon et al., 2008; Yang X. et al., 2012). Furthermore, a new class of satellite DNAs has been found to occur in association with the bipartite Sida golden yellow vein virus (Fiallo-Olivé et al., 2012). These satellite DNAs depend on the helper virus for encapsidation and systemic infection (Briddon and Stanley, 2006). Alphasatellites encode a Rep and are capable of autonomous replication in host plant cells (Saunders and Stanley, 1999). Betasatellites, which encode the $\beta C 1$ protein, depend on the helper virus for replication (Cui et al., 2005; Saunders et al., 2008), and may augment the accumulation and symptoms of their helper viruses (Briddon et al., 2003; Jyothsna et al., 2013; Patil and Fauquet, 2010) as a result of the interaction of $\beta C 1$ with SNF1-related kinase (Shen et al., 2012) and with $S$-adenosyl homocysteine hydrolase to suppress RNA silencing (Yang X. et al., 2012).

\section{CONCLUDING REMARKS}

Because of their very small genomes, geminiviruses have only four to eight proteins, some of which, most notably Rep/RepA, TrAP, and CP have evolved into multifunctional proteins to compensate for the small genomes. Protein multifunctionality is evidence of the plasticity through which evolution brings together functional domains into a single polypeptide chain; together with gene overlap it contributes to genetic economy exhibited by geminiviruses. In this review, current knowledge on the function of these proteins and their interactions with host proteins have been discussed. While many of these interactions and their biological functions have been elucidated, many are still poorly understood and more information will continue to be discovered so as to provide new opportunities in the design of virus control strategies.

\section{ACKNOWLEDGEMENTS}

I thank Linda Hanley-Bowdoin for critical reading of the manuscript. This work was supported by the National Science Foundation award \#0724083.

\section{REFERENCES}

Ach, R.A., Durfee, T., Miller, A.B., Taranto, P., Hanley-Bowdoin, L., Zambriski, P.C. and Gruissem, W. (1997) RRB1 and RRB2 encode maize retinoblastoma-related proteins that interact with a plant D-type cyclin and geminivirus replication protein. Mol. Cell. Biol. 17, 5077-5086.

Arai, K. and Kornberg, A. (1979) A general priming system employing only dnaB protein and primase for DNA replication. Proc. Natl. Acad. Sci. USA, 76, 4308-4312.

Arguello-Astorga, G., Lopez-Ochoa, L., Kong, L.J., Orozco, B.M., Settlage, S.B. and Hanley-Bowdoin, L. (2004) A novel motif in geminiviral replication proteins interacts with the plant retinoblastoma related protein. J. Virol. 78, 48174826.

Avvakumov, N., Sahbegovic, M., Zhang, Z., Shuen, M. and Mymryk, J.S. (2002) Analysis of DNA binding by the adenovirus type 5 E1A oncoprotein. J. Gen. Virol. 83, 517-524.

Böttcher, B., Unseld, S., Ceulemans, H., Russell, R.B. and Jeske, H. (2004) Geminate structures of African cassava mosaic virus. J. Virol. 78, 6758-6765.

Boulton, M.I., Steinkellner, H., Donson, J., Markham, P.G., King, D.I. and Davies, J.W. (1989) Mutational analysis of the virion-sense genes of maize streak virus. J. Gen. Virol. 70, 2309-2323.

Boulton, M.I., Pallaghy, C.K., Chatani, M., MacFarlane, S. and Davies, J.W. (1993) Replication of Maize streak virus mutants in maize protoplasts: evidence for a movement protein. Virology, 192, 85-93.

Boyne, J.R. and Whitehouse, A. (2006) Nucleolar trafficking is essential for nuclear export of intronless herpesvirus mRNA. Proc. Natl. Acad. Sci. USA, 103, 15190 15195.

Briddon, R.W. and Stanley, J. (2006) Subviral agents associated with plant singlestranded DNA viruses. Virology, 344, 198-210.

Briddon, R.W., Watts, J., Markham, P.G. and Stanley, J. (1989) The coat protein of Beet curly top virus is essential for infectivity. Virology, 172, 628-633.

Briddon, R.W., Pinner, M.S., Stanley, J. and Markham, P.G. (1990) Geminivirus coat protein replacement alters insect specificity. Virology, 177, 85-94.

Briddon, R.W., Bedford, I.D., Tsai, J.H. and Markham, P.G. (1996) Analysis of the nucleotide sequence of the treehopper-transmitted geminivirus, tomato pseudo-curly top virus, suggests a recombinant origin. Virology, 219, 387-394.

Briddon, R.W., Bull, S.E., Amin, I., Idris, A.M., Mansoor, S., Bedford, I.D., Dhawan, P., Rishi, N., Siwatch, S.S., Abdel-Salam, A.M., Brown, J.K., Zafar, Y. and Markham, P. (2003) Diversity of DNA $\beta$, a satellite molecule associated with some monopartite begomoviruses. Virology, 312, 106-121.

Briddon, R.W., Bull, S.E., Amin, I., Mansoor, S., Bedford, I.D., Rishi, N., Siwatch, S.S., Zafar, Y., Abdel-Salam, A.M. and Markham, P.G. (2004) Diversity of DNA 1 a satellite-like molecule associated with monopartite begomovirus-DNA beta complexes. Virology, 324, 462-474.

Briddon, R.W., Brown, J.K., Moriones, E., Stanley, J., Zerbini, M., Zhou, X. and Fauquet, C.M. (2008) Recommendations for the classification and nomenclature of the DNA- $\beta$ satellites of begomoviruses. Arch. Virol. 153, 763-781.

Brough, C.L., Hayes, R.J., Morgan, A.J., Coutts, R.H.A. and Buck, K.W. (1988) Effects of mutagenesis in vitro on the ability of cloned Tomato golden mosaic virus DNA to infect Nicotiana benthamiana plants. J. Gen. Virol. 69, 503-514.

Brown, J.K. (1994) Current status of Bemisia tabaci as a pest and virus vector in world agro-ecosystems. FAO Plant Prot. Bull. 42, 3-32.

Brown, J.K., Fauquet, C.M., Briddon, R.W., Zerbini, M., Moriones, E. and NavasCastillo, J. (2012) Family Geminiviridae. In: Virus Taxonomy: Classification and Nomenclature of Viruses-Ninth Report of the International Committee on Tax onomy of Viruses (King, A.M.Q., Adams, M.J., Carstens, E.B. and Lefkowitz, E.J., eds), pp. 351-373. London: Elsevier Academic Press.

Bull, S.E., Briddon, R.W., Sserubombwe, W.S., Ngugi, K., Markham, P.G. and Stanley, J. (2007) Infectivity, pseudorecombination and mutagenesis of Kenyan cassava mosaic begomoviruses. J. Gen. Virol. 88, 1624-1633.

Carvalho, C.M., Santos, A.A., Pires, S.R., Rocha, C.S., Saraiva, D.I., Machado, P.B., Mattos, E.C., Fietto, L.G. and Fontes, E.P.B. (2008a) Regulated nuclear trafficking of rpL10A mediated by NIK1 represents a defense strategy of plant cells against virus. PLoS Pathog. 4, e1000247.

Carvalho, C.M., Machado, J.P., Zerbini, F.M. and Fontes, E.P. (2008b) NSPinteracting GTPase: a cytosolic protein as cofactor for nuclear shuttle proteins. Plant Signal Behav. 3, 752-754.

Castellano, M.M., Sanz-Burgos, A.P. and Gutiérrez, C. (1999) Initiation of DNA replication in a eukaryotic rolling-circle replicon: identification of multiple DNAprotein complexes at the geminivirus origin. J. Mol. Biol. 290, 639-652. 
Castillo, A.G., Collinet, D., Deret, S., Kashoggi, A. and Bejarano, E.R. (2003) Dual interaction of plant PCNA with geminivirus replication accessory protein (Ren) and viral replication protein (Rep). Virology, 312, 381-394.

Castillo, A.G., Kong, L.J., Hanley-Bowdoin, L. and Bejarano, E.R. (2004) Interaction between a geminivirus replication protein and the plant sumoylation system. J. Virol. 78, 2758-2769.

Chandran, S.A., Levy, Y., Mett, A., Belausov, E., Ramakrishnan, U. and Gafni, Y. (2012) Mapping of functional region conferring nuclear localization and karyopherin $\alpha$-binding activity of the C2 protein of Bhendi yellow vein mosaic virus. J. Gen. Virol. 93, 1367-1374.

Chapman, E.R. (2008) How does synaptotagmin trigger neurotransmitter release? Annu. Rev. Biochem. 77, 615-641.

Chellappan, P., Vanitharani, R. and Fauquet, C.M. (2004) Short interfering RNA accumulation correlates with host recovery in DNA virus-infected hosts and gene silencing targets specific viral sequences. J. Virol. 78, 7465-7477.

Chowda-Reddy, R.V., Dong, W., Felton, C., Ryman, D., Ballard, K. and Fondong, V.N. (2009) Characterization of the cassava geminivirus transcription activation protein putative nuclear localization signal. Virus Res. 145, 270-278.

Chowda-Reddy, R.V.C., Achenjang, F., Felton, C., Etarock, M.T., Anangfac, M.T., Nugent, P. and Fondong, V.F. (2008) Role of a geminivirus AV2 protein putative protein kinase C motif on subcellular localization and pathogenicity. Virus Res. 135, 115-124.

Christensen, J. and Tattersall, P. (2002) Parvovirus initiator protein NS1 and RPA coordinate replication fork progression in a reconstituted DNA replication system. J. Virol. 76, 6518-6531.

Coll, N.S., Epple, P. and Dangl, J.L. (2011) Programmed cell death in the plant immune system. Cell Death Differ. 18, 1247-1256.

Collin, S., Fernandez-Lobato, M., Gooding, P.S., Mullineaux, P.M. and Fenoll, C. (1996) The two nonstructural proteins from Wheat dwarf virus involved in viral gene expression and replication are retinoblastoma-binding proteins. Virology, 219, 324329

Cui, X., Li, G., Wang, D., Hu, D. and Zhou, X. (2005) A begomovirus DNAß-encoded protein binds DNA, functions as a suppressor of RNA silencing, and targets the cell nucleus. J. Virol. 79, $10764-10775$.

Dekker, E.L., Woolston, C.J., Xue, Y.B., Cox, B. and Mullineaux, P.M. (1991) Transcript mapping reveals different expression strategies for the bicistronic RNAs of the geminivirus wheat dwarf virus. Nucleic Acids Res. 19, 4075-4081.

Desvoyes, B., Ramirez-Parra, E., Xie, Q., Chua, N.H. and Gutierrez, C. (2006) Cell type-specific role of the retinoblastoma/E2F pathway during Arabidopsis leaf development. Plant Physiol. 140, 67-80.

Dogra, S.C., Eini, O., Rezaian, M.A. and Randles, J.W. (2009) A novel shaggy-like kinase interacts with the Tomato leaf curl virus pathogenicity determinant C4 protein. Plant Mol. Biol. 71, 25-38.

Dong, X., van Wezel, R., Stanley, J. and Hong, Y. (2003) Functional characterization of the nuclear localization signal for a suppressor of posttranscriptional gene silencing. J. Virol. 77, 7026-7033.

Dry, I., Krake, L., Mullineaux, P. and Rezaian, A. (2000) Regulation of tomato leaf curl viral gene expression in host tissues. Mol. Plant-Microbe Interact. 13, 529-537.

Eagle, P.A., Orozco, B.M. and Hanley-Bowdoin, L. (1994) A DNA sequence required for geminivirus replication also mediates transcriptional regulation. Plant Cell, 6, 1157-1170.

Egelkrout, E.M., Robertson, D. and Hanley-Bowdoin, L. (2001) Proliferating cell nuclear antigen transcription is repressed through an E2F consensus element and activated by geminivirus infection in mature leaves. Plant Cell, 13, 1437-1452.

Elmer, J.S., Brand, L., Sunter, G., Gardiner, W.E., Bisaro, D.M. and Rogers, S.G. (1988) Genetic analysis of the tomato golden mosaic virus. II. Requirement for the product of the highly conserved ALI coding sequence for replication. Nucleic Acids Res. 16, 7043-7060.

Etessami, P., Watts, J. and Stanley, J. (1989) Size reversion of African cassava mosaic virus coat protein gene deletion mutants during infection of Nicotiana benthamiana. J. Gen. Virol. 70, 277-289.

Etessami, P., Saunders, K., Watts, J. and Stanley, J. (1991) Mutational analysis of complementary-sense genes of African cassava mosaic virus DNA A. J. Gen. Virol. 72, 1005-1012.

Fiallo-Olivé, E., Martínez-Zubiaur, Y., Moriones, E. and Navas-Castillo, J. (2012) A novel class of DNA satellites associated with New World begomoviruses. Virology, 426, 1-6.

Florentino, L.H., Santos, A.A., Fontenelle, M.R., Pinheiro, G.L., Zerbini, F.M., Baracat-Pereira, M.C. and Fontes, E.P. (2006) A PERK-like receptor kinase interacts with the geminivirus nuclear shuttle protein and potentiates viral infection. J. Virol. 80, 6648-6656.

Fondong, V.N., Reddy, R.V., Lu, C., Hankoua, B., Felton, C., Czymmek, K. and Achenjang, F. (2007) The consensus N-myristoylation motif of a geminivirus AC4 protein is required for membrane binding and pathogenicity. Mol. Plant-Microbe Interact. 20, 380-391.

Fontes, E.P., Santos, A.A., Luz, D.F., Waclawovsky, A.J. and Chory, J. (2004) The geminivirus nuclear shuttle protein is a virulence factor that suppresses transmembrane receptor kinase activity. Genes Dev. 18, 2545-2556.

Fontes, E.P.B., Luckow, V.A. and Hanley-Bowdoin, L. (1992) A geminivirus replication protein is a sequence-specific DNA binding protein. Plant Cell, 4, 597-608.

Fontes, E.P.B., Eagle, P.A., Sipe, P.S., Luckow, V.A. and Hanley-Bowdoin, L. (1994) Interaction between a geminivirus replication protein and origin DNA is essential for viral replication. J. Biol. Chem. 269, 8459-8465.

Frey, P.M., Scharer-Hernandez, N.G., Futterer, J., Potrykus, I. and Puonti-Kaerlas, J. (2001) Simultaneous analysis of the bidirectional African cassava mosaic virus promoter activity using two different luciferase genes. Virus Genes, 22, $231-$ 242.

Frischmuth, S., Wege, C., Hulser, D. and Jeske, H. (2007) The movement protein BC1 promotes redirection of the nuclear shuttle protein BV1 of Abutilon mosaic geminivirus to the plasma membrane in fission yeast. Protoplasma, 230, 117-123.

Fukuda, M. (2003) Molecular cloning, expression, and characterization of a novel class of synaptotagmin (Syt XIV) conserved from Drosophila to humans. J. Biochem. 133, 641-649.

Garrido-Ramirez, E.R., Sudarshana, M.R., Lucas, W.J. and Gilbertson, R.L. (2000) Bean dwarf mosaic virus BV1 protein is a determinant of the hypersensitive response and avirulence in Phaseolus vulgaris. Mol. Plant-Microbe Interact. 13, 1184-1194.

Geider, K., Beck, E. and Schaller, H. (1978) An RNA transcribed from DNA at the origin of phage fd single strand to replicative form conversion. Proc. Natl. Acad. Sci. USA, 75, 645-649.

Gibbs, A. and Ohshima, K. (2010) Potyviruses and the digital revolution. Annu. Rev. Phytopathol. 48, 205-223.

Gillette, W.K., Meade, T.J., Jeffrey, J.L. and Petty, I.T.D. (1998) Genetic determinants of host-specificity in bipartite geminivirus DNA A components. Virology, 251, 361 369.

Glick, E., Zrachya, A., Levy, Y., Mett, A., Gidoni, D., Belausov, E., Citovsky, V. and Gafni, Y. (2008) Interaction with host SGS3 is required for suppression of RNA silencing by Tomato yellow leaf curl virus V2 protein. Proc. Natl. Acad. Sci. USA, 105, 157-161.

Gröning, B.R., Hayes, R.J. and Buck, K.W. (1994) Simultaneous regulation of Tomato golden mosaic virus coat protein and AL1 gene expression: expression of the AL4 gene may contribute to suppression of the AL1 gene. J. Gen. Virol. 75, $721-726$.

Guerra-Peraza, O., Kirk, D., Seltzer, V., Veluthambi, K., Schmit, A.C., Hohn, T. and Herzog, E. (2005) Coat proteins of Rice tungro bacilliform virus and Mungbean yellow mosaic virus contain multiple nuclear-localization signals and interact with importin alpha. J. Gen. Virol. 86, 1815-1826.

Guevara-González, R.G., Ramos, P.L. and Rivera-Bustamante, R.F. (1999) Complementation of coat protein mutants of pepper huasteco geminivirus in transgenic tobacco plants. Phytopathology, 89, 540-545.

Gutierrez, C. (2000) DNA replication and cell cycle in plants: learning from geminiviruses. EMBO J. 19, 792-799.

Gutierrez, C., Ramirez-Parra, E., Mar Castellano, M., Sanz-Burgos, A.P., Luque, A. and Missich, R. (2004) Geminivirus DNA replication and cell cycle interactions. Vet. Microbiol. 98, 111-119.

Hadfield, J., Thomas, J.E., Schwinghamer, M.W., Kraberger, S., Stainton, D., Dayaram, A., Parry, J.N., Pande, D., Martin, D.P. and Varsani, A. (2012) Molecular characterisation of dicot-infecting mastreviruses from Australia. Virus Res. 166, $13-22$.

Haley, A., Zhan, X., Richardson, K., Head, K. and Morris, B. (1992) Regulation of the activities of African cassava mosaic virus promoters by the $\mathrm{AC1}, \mathrm{AC2}$, and $\mathrm{AC} 3$ gene products. Virology, 188, 905-909.

Hallan, V. and Gafni, Y. (2001) Tomato yellow leaf curl virus (TYLCV) capsid protein (CP) subunit interactions: implications for viral assembly. Arch. Virol. 146, 17651773

Hamilton, A., Voinnet, O., Chappell, L. and Baulcombe, D. (2002) Two classes of short interfering RNA in RNA silencing. EMBO J. 21, 4671-4679.

Hanley-Bowdoin, L., Settlage, S.B., Orozco, B.M., Nagar, S. and Robertson, D. (1999) Geminiviruses: models for plant DNA replication, transcription, and cell cycle regulation. Crit. Rev. Plant Sci. 18, 71-106. 
Hanley-Bowdoin, L., Settlage, S.B. and Robertson, D. (2004) Reprogramming plant gene expression: a prerequisite to geminivirus DNA replication. Mol. Plant. Pathol. 5, 149-156.

Hao, L., Wang, H., Sunter, G. and Bisaro, D.M. (2003) Geminivirus AL2 and L2 proteins interact with and inactivate SNF1 kinase. Plant Cell, 15, 1034-1048.

Hartitz, M.D., Sunter, G. and Bisaro, D.M. (1999) The Tomato golden mosaic virus transactivator (TrAP) is a single-stranded DNA and zinc-binding phosphoprotein with an acidic activation domain. Virology, 263, 1-14.

Hayes, R.J., Macdonald, H., Coutts, R.H.A. and Buck, K.W. (1988) Priming of complementary DNA synthesis in vitro by small DNA molecules tightly bound to virion DNA of wheat dwarf virus. J. Gen. Virol. 69, 1345-1350.

Hefferon, K.L. and Dugdale, B. (2003) Independent expression of Rep and RepA and their roles in regulating Bean yellow dwarf virus replication. J. Gen. Virol. 84, 3465-3472.

Hefferon, K.L., Moon, Y.S. and Fan, Y. (2006) Multi-tasking of nonstructural gene products is required for bean yellow dwarf geminivirus transcriptional regulation. FEBS J. 273, 4482-4494.

Hehnle, S., Wege, C. and Jeske, H. (2004) Interaction of DNA with the movement proteins of geminiviruses revisited. J. Virol. 78, 7698-7706.

Herranz, M.C., Pallas, V. and Aparicio, F. (2012) Multifunctional roles for the $\mathrm{N}$-terminal basic motif of Alfalfa mosaic virus coat protein: nucleolar/cytoplasmic shuttling, modulation of RNA-binding activity, and virion formation. Mol. PlantMicrobe Interact. 25, 1093-1103.

Heyraud-Nitschke, F., Schumacher, S., Laufs, J., Schaefer, S., Schell, J. and Gronenborn, B. (1995) Determination of the origin cleavage and joining domain of geminivirus Rep proteins. Nucleic Acids Res. 23, 910-916.

Hiscox, J.A., Wurm, T., Wilson, L., Britton, P., Cavanagh, D. and Brooks, G. (2001) The coronavirus infectious bronchitis virus nucleoprotein localizes to the nucleolus. J. Virol. 75, 506-512.

Hofer, J.M., Dekker, E.L., Reynolds, H.V., Woolston, C.J., Cox, B.S. and Mullineaux, P.M. (1992) Coordinate regulation of replication and virion sense gene expression in wheat dwarf virus. Plant Cell, 4, 213-223.

Hohnle, M., Hofer, P., Bedford, I.D., Briddon, R.W., Markham, P.G. and Frischmuth, T. (2001) Exchange of three amino acids in the coat protein results in efficient whitefly transmission of a nontransmissible Abutilon mosaic virus isolate. Virology, 290, 164-171.

Hong, Y. and Stanley, J. (1995) Regulation of African cassava mosaic virus complementary-sense gene expression by $\mathrm{N}$-terminal sequences of the replicationassociated protein AC1. J. Gen. Virol. 76, 2415-2422.

Hong, Y., Saunders, K., Hartley, M.R. and Stanley, J. (1996) Resistance to geminivirus infection by virus-induced expression of dianthin in transgenic plants. Virology, 220, 119-127.

Hoogstraten, R.A., Hanson, S.F. and Maxwell, D.P. (1996) Mutational analysis of the putative nicking motif in the replication-associated protein $(\mathrm{AC1})$ of bean golden mosaic geminivirus. Mol. Plant-Microbe Interact. 9, 594-599.

Hormuzdi, S.G. and Bisaro, D.M. (1995) Genetic analysis of beet curly top virus: examination of the roles of L2 and L3 genes in viral pathogenesis. Virology, 206, 1044-1054.

Horvath, G.V., Pettko-Szandtner, A., Nikovics, K., Bilgin, M., Boulton, M., Davies, J.W., Gutierrez, C. and Dudits, D. (1998) Prediction of functional regions of the Maize streak virus replication-associated proteins by protein-protein interaction analysis. Plant Mol. Biol. 38, 699-712.

Hughes, F.L., Rybicki, E.P. and Kirby, R. (1993) Complete nucleotide sequence of sugarcane streak monogeminivirus. Arch. Virol. 132, 171-182.

Hussain, M., Mansoor, S., Iram, S., Fatima, A.N. and Zafar, Y. (2005) The nuclear shuttle protein of Tomato leaf curl New Delhi virus is a pathogenicity determinant. J. Virol. 79, 4434-4439.

Hussain, M., Mansoor, S., Iram, S., Zafar, Y. and Briddon, R.W. (2007) The hypersensitive response to Tomato leaf curl New Delhi virus nuclear shuttle protein is inhibited by transcriptional activator protein. Mol. Plant-Microbe Interact. 20, 15811588.

Ilyina, T.V. and Koonin, E.V. (1992) Conserved sequence motifs in the initiator proteins for rolling circle DNA replication encoded by diverse replicons from eubacteria, eucaryotes and archaebacteria. Nucleic Acids Res. 20, 3279-3285.

Ingham, D.J., Pascal, E. and Lazarowitz, S.G. (1995) Both bipartite geminivirus movement proteins define viral host range, but only BL1 determines viral pathogenicity. Virology, 207, 191-204.

Jeske, H. (2009) Geminiviruses. Curr. Top. Microbiol. Immunol. 331, 185-226.

Jordan, C.V., Shen, W., Hanley-Bowdoin, L.K. and Robertson, D.N. (2007) Geminivirus-induced gene silencing of the tobacco retinoblastoma-related gene results in cell death and altered development. Plant Mol. Biol. 65, 163175.

Jupin, I., De Kouchkovsky, F., Jouanneau, F. and Gronenborn, B. (1994) Movement of tomato yellow leaf curl geminivirus (TYLCV): involvement of the protein encoded by ORF C4. Virology, 204, 82-90.

Jyothsna, P., Haq, Q.M., Singh, P., Sumiya, K.V., Praveen, S., Rawat, R., Briddon, R.W. and Malathi, V.G. (2013) Infection of Tomato leaf curl New Delhi virus (ToLCNDV), a bipartite begomovirus with betasatellites, results in enhanced level of helper virus components and antagonistic interaction between DNA B and betasatellites. Appl. Microbiol. Biotechnol. [Epub ahead of print].

Kammann, M., Schalk, H.J., Matzeit, V., Schaefer, S., Schell, J. and Gronenborn, B. (1991) DNA replication of wheat dwarf virus, a geminivirus, requires two cis-acting signals. Virology, 184, 786-790.

Kheyr-Pour, A., Bananej, K., Dafalla, G.A., Caciagli, P., Noris, E., Ahoonmanesh, A., Lecoq, H. and Gronenborn, B. (2000) Watermelon chlorotic stunt virus from the Sudan and Iran: sequence comparisons and identification of a whitefly-transmission determinant. Phytopathology, 90, 629-635.

Kim, K.S. and Lee, K.W. (1992) Geminivirus-induced macrotubules and their suggested role in cell-to-cell movement. Phytopathology, 82, 664-669.

Kim, S.H., Macfarlane, S., Kalinina, N.O., Rakitina, D.V., Ryabov, E.V., Gillespie, T., Haupt, S., Brown, J.W. and Taliansky, M. (2007a) Interaction of a plant virusencoded protein with the major nucleolar protein fibrillarin is required for systemic virus infection. Proc. Natl. Acad. Sci. USA, 104, 11115-11120.

Kim, S.H., Ryabov, E.V., Kalinina, N.O., Rakitina, D.V., Gillespie, T., Macfarlane, S., Haupt, S., Brown, J.W. and Taliansky, M. (2007b) Cajal bodies and the nucleolus are required for a plant virus systemic infection. EMBO J. 26, 21692179.

Kleinow, T., Tanwir, F., Kocher, C., Krenz, B., Wege, C. and Jeske, H. (2009) Expression dynamics and ultrastructural localization of epitope-tagged Abutilon mosaic virus nuclear shuttle and movement proteins in Nicotiana benthamiana cells. Virology, 391, 212-220.

Kong, L.J. and Hanley-Bowdoin, L. (2002) A geminivirus replication protein interacts with a protein kinase and a motor protein that display different expression patterns during plant development and infection. Plant Cell, 14, 1817-1832.

Kong, L.-J., Orozco, B.M., Roe, J.R., Nagar, S., Ou, S., Feiler, H.S., Durfee, T., Miller, A.B., Gruissem, W., Robertson, D. and Hanley-Bowdoin, L. (2000) A geminivirus replication protein interacts with the retinoblastoma protein through a novel domain to determine symptoms and tissue specificity of infection in plants. EMBO J. 19, 3485-3495.

Kotlitzky, G., Boulton, M.I., Pitaksutheepong, C., Davies, J.W. and Epel, B. (2000) Intracellular and intercellular movement of maize streak geminivirus V1 and V2 proteins transiently expressed as green fluorescent protein fusions. Virology, 274, 32-38.

Krenz, B., Wege, C. and Jeske, H. (2010) Cell-free construction of disarmed Abutilon mosaic virus-based gene silencing vectors. J. Virol. Methods, 169, 129-137.

Krenz, B., Neugart, F., Kleinow, T. and Jeske, H. (2011) Self-interaction of Abutilon mosaic virus replication initiator protein (Rep) in plant cell nuclei. Virus Res. 161, 194-197.

Krenz, B., Jeske, H. and Kleinow, T. (2012) The induction of stromule formation by a plant DNA-virus in epidermal leaf tissues suggests a novel intra- and intercellular macromolecular trafficking route. Front Plant Sci. 3, 291.

Kreuze, J.F., Perez, A., Untiveros, M., Quispe, D., Fuentes, S., Barker, I. and Simon, R. (2009) Complete viral genome sequence and discovery of novel viruses by deep sequencing of small RNAs: a generic method for diagnosis, discovery and sequencing of viruses. Virology, 388, 1-7.

Krichevsky, A., Kozlovsky, S.V., Gafni, Y. and Citovsky, V. (2006) Nuclear import and export of plant virus proteins and genomes. Mol. Plant Pathol. 7, 131-146.

Krupovic, M., Ravantti, J.J. and Bamford, D.H. (2009) Geminiviruses: a tale of a plasmid becoming a virus. BMC Evol. Biol. 9, 112.

Kunik, T., Palanichelvam, K., Czosnek, H., Citovsky, V. and Gafni, Y. (1998) Nuclear import of the capsid protein of Tomato yellow leaf curl virus (TYLCV) in plant and insect cells. Plant J. 13, 393-399.

Kunik, T., Mizrachy, L., Citovsky, V. and Gafni, Y. (1999) Characterization of a tomato karyopherin alpha that interacts with the Tomato yellow leaf curl virus (TYLCV) capsid protein. J. Exp. Bot. 50, 731-732.

Lacatus, G. and Sunter, G. (2009) The Arabidopsis PEAPOD2 transcription factor interacts with geminivirus AL2 protein and the coat protein promoter. Virology, 392, 196-202.

Lai, J., Chen, H., Teng, K., Zhao, Q., Zhang, Z., Li, Y., Liang, L., Xia, R., Wu, Y., Guo, H. and Xie, Q. (2009) RKP, a RING finger E3 ligase induced by BSCTV C4 protein 
affects geminivirus infection by regulation of the plant cell cycle. Plant J. 57, 905917.

Latham, J.R., Saunders, K., Pinner, M.S. and Stanley, J. (1997) Induction of plant cell division by Beet curly top virus gene C4. Plant J. 11, 1273-1283.

Laufs, J., Jupin, I., David, C., Schumacher, S., Heyraud-Nitschke, F. and Gronenborn, B. (1995) Geminivirus replication: genetic and biochemical characterization of rep protein function, a review. Biochimie, 77, 765-773.

Lazarowitz, S.G. and Beachy, R.N. (1999) Viral movement proteins as probes for intracellular and intercellular trafficking in plants. Plant Cell, 11, 535-548.

Lazarowitz, S.G., Wu, L.C., Rogers, S.G. and Elmer, J.S. (1992) Sequence-specific interaction with the viral AL1 protein identifies a geminivirus DNA replication origin. Plant Cell, 4, 799-809.

Lewis, J.D. and Lazarowitz, S.G. (2010) Arabidopsis synaptotagmin SYTA regulates endocytosis and virus movement protein cell-to-cell transport. Proc. Natl. Acad. Sci. USA, 107, 2491-2496.

Liu, H., Boulton, M.I. and Davies, J.W. (1997) Maize streak virus coat protein binds single- and double-stranded DNA in vitro. J. Gen. Virol. 78, 1265-1270.

Liu, H., Lucy, A.P., Davies, J. and Boulton, M.I. (2001) A single amino acid change in the coat protein of Maize streak virus abolishes systemic infection, but not interaction with viral DNA or movement protein. Mol. Plant Pathol. 2, 223-228.

Liu, L., Saunders, K., Thomas, C.L., Davies, J.W. and Stanley, J. (1999) Bean yellow dwarf virus RepA, but not Rep, binds to maize retinoblastoma protein, and the virus tolerates mutations in the consensus binding motif. Virology, 256, 270279

Loo, Y.M. and Melendy, T. (2004) Recruitment of Replication protein A by the papillomavirus E1 protein and modulation by single-stranded DNA. J. Virol. 78, 16051615.

Loor, G., Zhang, S., Zhang, P., Toomey, N.L. and Lee, M.Y.W. (1997) Identification of DNA replication and cell cycle proteins that interact with PCNA. Nucleic Acids Res. 25, 5041-5046.

Lozano-Duran, R., Rosas-Diaz, T., Gusmaroli, G., Luna, A.P., Taconnat, L., Deng, X.W. and Bejarano, E.R. (2011) Geminiviruses subvert ubiquitination by altering CSN-mediated derubylation of SCF E3 ligase complexes and inhibit jasmonate signaling in Arabidopsis thaliana. Plant Cell, 23, 1014-1032.

Luque, A., Sanz-Burgos, A.P., Ramirez-Parra, E., Castellano, M.M. and Gutierrez, C. (2002) Interaction of geminivirus Rep protein with replication factor $C$ and its potential role during geminivirus DNA replication. Virology, 302, 83-94.

Mankertz, A. and Hillenbrand, B. (2001) Replication of porcine circovirus type 1 requires two proteins encoded by the viral rep gene. Virology, 279, 429-438.

McGarry, R.C., Barron, Y.D., Carvalho, M.F., Hill, J.E., Gold, D., Cheung, E., Kraus, W.L. and Lazarowitz, S.G. (2003) A novel Arabidopsis acetyltransferase interacts with the geminivirus movement protein NSP. Plant Cell, 15, 1605-1618.

Mills-Lujan, K. and Deom, C.M. (2010) Geminivirus C4 protein alters Arabidopsis development. Protoplasma, 239, 95-110.

Mori, T., Takenaka, K., Domoto, F., Aoyama, Y. and Sera, T. (2012) Inhibition of binding of Tomato yellow leaf curl virus Rep to its replication origin by artificial zinc-finger protein. Mol. Biotechnol. [Epub ahead of print].

Morin, S., Ghanim, M., Sobol, I. and Czosnek, H. (2000) The GroEL protein of the whitefly Bemisia tabaci interacts with the coat protein of transmissible and nontransmissible begomoviruses in the yeast two-hybrid system. Virology, 276, 404416

Mubin, M., Amin, I., Amrao, L., Briddon, R.W. and Mansoor, S. (2010) The hypersensitive response induced by the V2 protein of a monopartite begomovirus is countered by the C2 protein. Mol. Plant Pathol. 11, 245-254.

Mullineaux, P.M., Donson, J., Morris-Krsinich, B.A.M., Boulton, M.I. and Davies, J.W. (1984) The nucleotide sequence of Maize streak virus DNA. EMBO J. 3, 30633068.

Mullineaux, P.M., Boulton, M.I., Bowyer, P., van Der Vlugt, R., Marks, M., Donson, J. and Davies, J.W. (1988) Detection of a non-structural protein of MW11000 encoded by the virion DNA of Maize streak virus. Plant Mol. Biol. 11, 57-66.

Mullineaux, P.M., Guerineau, F. and Accotto, G.P. (1990) Processing of complementary sense RNAs of Digitaria streak virus in its host and in transgenic tobacco. Nucleic Acids Res. 18, 7259-7265.

Munoz-Martin, A., Collin, S., Herreros, E., Mullineaux, P.M., Fernandez-Lobato, M. and Fenoll, C. (2003) Regulation of MSV and WDV virion-sense promoters by WDV nonstructural proteins: a role for their retinoblastoma protein-binding motifs. Virology, 306, 313-323.

Nahid, N., Amin, I., Mansoor, S., Rybicki, E.P., van der Walt, E. and Briddon, R.W. (2008) Two dicot-infecting mastreviruses (family Geminiviridae) occur in Pakistan. Arch. Virol. 153, 1441-1451.
Nash, T.E., Dallas, M.B., Reyes, M.I., Buhrman, G.K., Ascencio-Ibañez, J.T. and Hanley-Bowdoin, L. (2011) Functional analysis of a novel motif conserved across geminivirus Rep proteins. J. Virol. 85, 1182-1192.

Noris, E., Vaira, A.M., Caciagli, P., Masenga, V., Gronenborn, B. and Accotto, G.P. (1998) Amino acids in the capsid protein of Tomato yellow leaf curl virus that are crucial for systemic infection, particle formation, and insect transmission. J. Virol. 72 10 050-10 057.

Noueiry, A.O., Lucas, W.J. and Gilbertson, R.L. (1994) Two proteins of a plant DNA virus coordinate nuclear and plasmodesmal transport. Cell, 76, 925-932.

Orozco, B.M. and Hanley-Bowdoin, L. (1998) Conserved sequence and structural motifs contribute to the DNA binding and cleavage activities of a geminivirus replication protein. J. Biol. Chem. 273, 24 448-24 456.

Orozco, B.M., Miller, A.B., Settlage, S.B. and Hanley-Bowdoin, L. (1997) Functional domains of a geminivirus replication protein. J. Biol. Chem. 272, 98409846.

Oshima, K., Kakizawa, S., Nishigawa, H., Kuboyama, T., Miyata, S., Ugaki, M. and Namba, S. (2001) A plasmid of phytoplasma encodes a unique replication protein having both plasmid- and virus-like domains: clue to viral ancestry or result of virus/plasmid recombination? Virology, 285, 270-277.

Padidam, M., Beachy, R.N. and Fauquet, C.M. (1995) Tomato leaf curl geminivirus from India has a bipartite genome and coat protein is not essential for infectivity. J. Gen. Virol. 76, 25-35.

Padidam, M., Beachy, R.N. and Fauquet, C.M. (1996) The role of AV2 ('precoat') and coat protein in viral replication and movement in tomato leaf curl geminivirus. Virology, 224, 390-404.

Padidam, M., Beachy, R.N. and Fauquet, C.M. (1999) A phage single-stranded DNA (ssDNA) binding protein complements ssDNA accumulation of a geminivirus and interferes with viral movement. J. Virol. 73, 1609-1616.

Pantaleo, V. (2011) Plant RNA silencing in viral defence. Adv. Exp. Med. Biol. 722, 39-58.

Paprotka, T., Metzler, V. and Jeske, H. (2010) The first DNA 1-like $\alpha$ satellites in association with New World begomoviruses in natural infections. Virology, 404, 148-157.

Park, J., Lee, H.J., Cheon, C.I., Kim, S.H., Hur, Y.S., Auh, C.K., Im, K.H., Yun, D.J., Lee, S. and Davis, K.R. (2011) The Arabidopsis thaliana homeobox gene ATHB12 is involved in symptom development caused by geminivirus infection. PLOS ONE, 6 , e20054.

Pascal, E., Sanderfoot, A.A., Ward, B.M., Medville, R., Turgeon, R. and Lazarowitz, S.G. (1994) The geminivirus BR1 movement protein binds single-stranded DNA and localizes to the cell nucleus. Plant Cell, 6, 995-1006.

Pasumarthy, K.K., Choudhury, N.R. and Mukherjee, S.K. (2010) Tomato leaf curl Kerala virus (ToLCKeV) AC3 protein forms a higher order oligomer and enhances ATPase activity of replication initiator protein (Rep/AC1). Virol. J. 7, 128.

Patil, B.L. and Fauquet, C.M. (2010) Differential interaction between cassava mosaic geminiviruses and geminivirus satellites. J. Gen. Virol. 91, 1871-1882.

Pavlov, Y.I., Maki, S., Maki, H. and Kunkel, T.A. (2004) Evidence for interplay among yeast replicative DNA polymerases $\alpha, \delta$ and $\varepsilon$ from studies of exonuclease and polymerase active site mutations. BMC Biol. 2, 11 .

Piroux, N., Saunders, K., Page, A. and Stanley, J. (2007) Geminivirus pathogenicity protein C4 interacts with Arabidopsis thaliana shaggy-related protein kinase AtSKeta, a component of the brassinosteroid signalling pathway. Virology, 362, $428-440$.

Pitaksutheepong, C. (1999) Biological and functional aspects of the movement proteins of Maize streak virus and Bean yellow dwarf virus in transgenic plants. PhD Thesis, University of East Anglia, Norwich, Norfolk.

Pitaksutheepong, C., Vimoltat, A., Nathwong, B. and Attathom, S. (2007) The N-terminal 62 amino acid residues of the coat protein of Tomato yellow leaf curl Thailand virus are responsible for DNA binding. J. Gen. Plant Pathol. 73, $72-75$.

Pooma, W. and Petty, I.T. (1996) Tomato golden mosaic virus open reading frame AL4 is genetically distinct from its C4 analogue in monopartite geminiviruses. J. Gen. Virol. 77, 1947-1951.

Pooma, W., Gillette, W.K., Jeffrey, J.L. and Petty, I.T.D. (1996) Host and viral factors determine the dispensability of coat protein for bipartite geminivirus systemic movement. Virology, 218, 264-268.

Poornima, P.C.G., Ambika, M.V., Tippeswamy, R. and Savithri, H.S. (2011) Functional characterization of coat protein and V2 involved in cell to cell movement of Cotton leaf curl Kokhran virus-Dabawali. PLoS ONE, 6, e26929.

Postel, S. and Kemmerling, B. (2009) Plant systems for recognition of pathogenassociated molecular patterns. Semin. Cell Dev. Biol. 20, 1025-1031. 
Qin, S., Ward, B.M. and Lazarowitz, S.G. (1998) The bipartite geminivirus coat protein aids BR1 function in viral movement by affecting the accumulation of viral singlestranded DNA. J. Virol. 72, 9247-9256.

Radhakrishnan, G.K., Splitter, G.A. and Usha, R. (2008) DNA recognition properties of the cell-to-cell movement protein (MP) of soybean isolate of Mungbean yellow mosaic India virus (MYMIV-Sb). Virus Res. 131, 152-159.

Rana, V.S., Singh, S.T., Priya, N.G., Kumar, J. and Rajagopal, R. (2012) Arsenophonus GroEL interacts with CLCuV and is localized in midgut and salivary gland of whitefly B. tabaci. PLoS ONE, 7, e42168.

Rigden, J.E., Dry, I.B., Mullineaux, P.M. and Rezaian, M.A. (1993) Mutagenesis of the virion-sense open reading frames of tomato leaf curl virus. Virology, 193, 10011005.

Rigden, J.E., Krake, L.R., Rezaian, M.A. and Dry, I.B. (1994) ORF C4 of tomato leaf curl geminivirus is a determinant of symptom severity. Virology, 204, 847-850.

Roberts, I.M. (1989) Indian cassava mosaic virus: ultrastructure of infected cells. J. Gen. Virol. 70, 2729-2739.

Rocha, C.S., Santos, A.A., Machado, J.P. and Fontes, E.P. (2008) The ribosomal protein L10/QM-like protein is a component of the NIK-mediated antiviral signaling. Virology, 38, 165-169.

Rojas, M.R., Noueiry, A.O., Lucas, W.J. and Gilbertson, R.L. (1998) Bean dwarf mosaic geminivirus movement proteins recognize DNA in a form- and size-specific manner. Cell, 95, 105-113.

Rojas, M.R., Jiang, H., Salati, R., Xoconostle-Cazares, B., Sudarshana, M.R., Lucas, W.J. and Gilbertson, R.L. (2001) Functional analysis of proteins involved in movement of the monopartite begomovirus, Tomato yellow leaf curl virus. Virology, 291, 110-125.

Romay, G., Chirinos, D., Geraud-Pouey, F. and Desvies, C. (2010) Association of an atypical alphasatellite with a bipartite New World begomovirus. Arch. Virol. 155, 1843-1847.

Rosario, K., Padilla-Rodriguez, M., Kraberger, S., Stainton, D., Martin, D.P., Breitbart, M. and Varsani, A. (2013) Discovery of a novel mastrevirus and alphasatellitelike circular DNA in dragonflies (Epiprocta) from Puerto Rico. Virus Res. 171, 231237.

Rouhibakhsh, A., Haq, Q. and Malathi, V.G. (2011) Mutagenesis in ORF AV2 affects viral replication in Mungbean yellow mosaic India virus. J. Biosci. 36, 329-340.

Saccardo, F., Cettul, E., Palmano, S., Noris, E. and Firrao, G. (2011) On the alleged origin of geminiviruses from extrachromosomal DNAs of phytoplasmas. BMC Evol. Biol. 11, 185.

Saeed, M., Zafar, Y., Randles, J.W. and Rezaian, M.A. (2007) A monopartite begomovirus-associated DNA beta satellite substitutes for the DNA B of a bipartite begomovirus to permit systemic infection. J. Gen. Virol. 88, 2881-2889.

Sakamoto, T., Deguchi, M., Brustolini, O.J., Santos, A.A., Silva, F.F. and Fontes, E.P. (2012) The tomato RLK superfamily: phylogeny and functional predictions about the role of the LRRII-RLK subfamily in antiviral defense. BMC Plant Biol. 12, 229.

Sánchez-Durán, M.A., Dallas, M.B., Ascencio-Ibañez, J.T., Reyes, M.I., ArroyoMateos, M., Ruiz-Albert, J., Hanley-Bowdoin, L. and Bejarano, E. (2011) Interaction between geminivirus replication protein and the SUMO-conjugating enzyme is required for viral infection. J. Virol. 85, 9789-9800.

Sanderfoot, A.A. and Lazarowitz, S.G. (1995) Cooperation in viral movement: the geminivirus BL1 movement protein interacts with BR1 and redirects it from the nucleus to the cell periphery. Plant Cell, 7, 1185-1194.

Sanderfoot, A.A., Ingham, D.J. and Lazarowitz, S.G. (1996) A viral movement protein as a nuclear shuttle-The geminivirus BR1 movement protein contains domains essential for interaction with BL1 and nuclear localization. Plant Physiol. 110, 23-33.

Santos, A.A., Carvalho, C.M., Florentino, L.H., Ramos, H.J. and Fontes, E.P. (2009) Conserved threonine residues within the A-loop of the receptor NIK differentially regulate the kinase function required for antiviral signaling. PLOS ONE, 4, e5781.

Sanz-Burgos, A.P. and Gutiérrez, C. (1998) Organization of the cis-acting element required for wheat dwarf geminivirus DNA replication and visualization of a rep protein-DNA complex. Virology, 243, 119-129.

Saunders, K. and Stanley, J. (1995) Complementation of African cassava mosaic virus AC2 gene function in a mixed bipartite geminivirus infection. J. Gen. Virol. 76, 2287-2292.

Saunders, K. and Stanley, J. (1999) A nanovirus-like DNA component associated with yellow vein disease of Ageratum conyzoides: evidence for interfamilial recombination between plant DNA viruses. Virology, 264, 142-152.

Saunders, K., Lucy, A. and Stanley, J. (1991) DNA forms of the geminivirus African cassava mosaic virus consistent with a rolling circle mechanism of replication. Nucleic Acids Res. 19, 2325-2330.
Saunders, K., Briddon, R.W. and Stanley, J. (2008) Replication promiscuity of DNA- $\beta$ satellites associated with monopartite begomoviruses; deletion mutagenesis of the Ageratum yellow vein virus DNA- $\beta$ satellite localizes sequences involved in replication. J. Gen. Virol. 89, 3165-3172.

Scholthof, K.B., Adkins, S., Czosnek, H., Palukaitis, P., Jacquot, E., Hohn, T., Hohn, B., Saunders, K., Candresse, T., Ahlquist, P., Hemenway, C. and Foster, G. (2011) Top 10 plant viruses in molecular plant pathology. Mol. Plant Pathol. 12, 938-954.

Selth, L.A., Randles, J.W. and Rezaian, M.A. (2004) Host responses to transient expression of individual genes encoded by Tomato leaf curl virus. Mol. PlantMicrobe Interact. 17, 27-33.

Selth, L.A., Dogra, S.C., Rasheed, M.S., Healy, H., Randles, J.W. and Rezaian, M.A. (2005) A NAC domain protein interacts with Tomato leaf curl virus replication accessory protein and enhances viral replication. Plant Cell, 17, 311-325.

Seo, Y.S., Gepts, P. and Gilbertson, R.L. (2004) Genetics of resistance to the geminivirus, Bean dwarf mosaic virus, and the role of the hypersensitive response in common bean. Theor. Appl. Genet. 108, 786-793.

Settlage, S.B., Miller, A.B., Gruissem, W. and Hanley-Bowdoin, L. (2001) Dual interaction of a geminivirus replication accessory factor with a viral replication protein and a plant cell cycle regulator. Virology, 279, 570-576.

Settlage, S.B., See, R.G. and Hanley-Bowdoin, L. (2005) Geminivirus C3 protein: replication enhancement and protein interactions. J. Virol. 79, 9885-9895.

Sharma, P. and Ikegami, M. (2009) Characterization of signals that dictate nuclear/ nucleolar and cytoplasmic shuttling of the capsid protein of Tomato leaf curl java virus associated with DNA beta satellite. Virus Res. 144, 145-153.

Sharma, P. and Ikegami, M. (2010) Tomato leaf curl Java virus V2 protein is a determinant of virulence, hypersensitive response and suppression of posttranscriptional gene silencing. Virology, 396, 85-93.

Sharma, P., Ikegami, M. and Kon, T. (2010) Identification of the virulence factors and suppressors of posttranscriptional gene silencing encoded by Ageratum yellow vein virus, a monopartite begomovirus. Virus Res. 149, 19-27.

Shen, Q., Bao, M. and Zhou, X. (2012) A plant kinase plays roles in defense response against geminivirus by phosphorylation of a viral pathogenesis protein. Plant Signal Behav. 7, 888-892.

Shen, W.H. and Hohn, B. (1991) Mutational analysis of the small intergenic region of Maize streak virus. Virology, 183, 721-730.

Shivaprasad, P.V., Akbergenov, R., Trinks, D., Rajeswaran, R., Veluthambi, K., Hohn, T. and Pooggin, M.M. (2005) Promoters, transcripts, and regulatory proteins of Mungbean yellow mosaic geminivirus. J. Virol. 79, 8149-8163.

Singh, D.K., Islam, M.N., Choudhury, N.R., Karjee, S. and Mukherjee, S.K. (2007) The $32 \mathrm{kDa}$ subunit of replication protein A (RPA) participates in the DNA replication of Mung bean yellow mosaic India virus (MYMIV) by interacting with the viral Rep protein. Nucleic Acids Res. 35, 755-770.

Singh, D.K., Malik, P.S., Choudhury, N.R. and Mukherjee, S.K. (2008) MYMIV replication initiator protein (Rep): roles at the initiation and elongation steps of MYMIV DNA replication. Virology, 380, 75-83.

Soto, M.J. (2001) Intracellular distribution of the three virion-sense encoded proteins of Beet curly top virus. Phytopathology, 91, S83.

Stanley, J. (2004) Subviral DNAs associated with geminivirus disease complexes. Vet Microbiol. 8, 121-129.

Stanley, J. and Gay, M.R. (1983) Nucleotide sequence of Cassava latent virus DNA Nature, 301, 260-262.

Stanley, J. and Latham, J.R. (1992) A symptom variant of beet curly top geminivirus produced by mutation of open reading frame C4. Virology, 190, 506-509.

Stanley, J. and Townsend, R. (1986) Infectious mutants of Cassava latent virus generated in vivo from intact recombinant DNA clones containing single copies of the genome. Nucleic Acids Res. 14, 5981-5998.

Stanley, J., Markham, P.G., Callis, R.J. and Pinner, M.S. (1986) The nucleotide sequence of an infectious clone of the geminivirus Beet curly top virus. EMBO J. 5, 1761-1767.

Stanley, J., Latham, J., Pinner, M.S., Bedford, I. and Markham, P.G. (1992) Mutational analysis of the monopartite geminivirus Beet curly top virus. Virology, 191, 396-405.

Steinfeldt, T., Finsterbusch, T. and Mankertz, A. (2006) Demonstration of nicking/ joining activity at the origin of DNA replication associated with the Rep and Rep' proteins of porcine circovirus type 1. J. Virol. 80, 6225-6234.

Stenger, D.C., Revington, G.N., Stevenson, M.C. and Bisaro, D.M. (1991) Replicational release of geminivirus genomes from tandemly repeated copies: evidence for rolling-circle replication of a plant viral DNA. Proc. Natl. Acad. Sci. USA, 88, 80298033. 
Sudarshana, M.R., Wang, H.L., Lucas, W.J. and Gilbertson, R.L. (1998) Dynamics of bean dwarf mosaic geminivirus cell-to-cell and long distance movement in Phaseolus vulgaris revealed, using the green fluorescent protein. Mol. Plant-Microbe Interact. 11, 277-291.

Sung, Y.K. and Coutts, R.H. (1995) Mutational analysis of potato yellow mosaic geminivirus. J. Gen. Virol. 76, 1773-1780.

Sunter, G. and Bisaro, D.M. (1992) Transactivation of geminivirus AR1 and BR1 gene expression by the viral AL2 gene product occurs at the level of transcription. Plant Cell, 4, 1321-1331.

Sunter, G. and Bisaro, D.M. (1997) Regulation of a geminivirus coat protein promoter by AL2 protein (TrAP): evidence for activation and derepression mechanisms. Virology, 232, 269-280

Sunter, G., Hertitz, M.D., Hormuzdi, S.G., Brough, C.L. and Bisaro, D.M. (1990) Genetic analysis of tomato golden mosaic virus: ORF AL2 is required for coat protein accumulation while ORF AL3 is necessary for efficient DNA replication. Virology, 179, 69-77.

Sunter, G., Stenger, D.C. and Bisaro, D.M. (1994) Heterologous complementation by geminivirus AL2 and AL3 genes. Virology, 203, 203-210.

Sunter, G., Sunter, J.L. and Bisaro, D.M. (2001) Plants expressing Tomato golden mosaic virus AL2 or Beet curly top virus L2 transgenes show enhanced susceptibility to infection by DNA and RNA viruses. Virology, 285, 59-70.

Teng, K., Chen, H., Lai, J., Zhang, Z., Fang, Y., Xia, R., Zhou, X., Guo, H. and Xie, Q. (2010) Involvement of C4 protein of Beet severe curly top virus (family Geminiviridae) in virus movement. PLOS ONE, 5, e11280.

Trinks, D., Rajeswaran, R., Shivaprasad, P.V., Akbergenov, R., Oakeley, E.J., Veluthambi, K., Hohn, T. and Pooggin, M.M. (2005) Suppression of RNA silencing by a geminivirus nuclear protein, $\mathrm{AC2}$, correlates with transactivation of host genes. J. Virol. 79, 2517-2527.

Unseld, S., Hohnle, M., Ringel, M. and Frischmuth, T. (2001) Subcellular targeting of the coat protein of African cassava mosaic geminivirus. Virology, 286, 373-383.

Vanitharani, R., Chellappan, P., Pita, J.S. and Fauquet, C.M. (2004) Differential roles of AC2 and AC4 of cassava geminiviruses in mediating synergism and suppression of posttranscriptional gene silencing. J. Virol. 78, 9487-9498.

Vanitharani, R., Chellappan, P. and Fauquet, C.M. (2005) Geminiviruses and RNA silencing. Trends Plant Sci. 10, 144-151.

Voinnet, O., Pinto, Y.M. and Baulcombe, D.C. (1999) Suppression of gene silencing: a general strategy used by diverse DNA and RNA viruses of plants. Proc. Natl. Acad. Sci. USA, 96, 14 147-14 152.

Walsh, D. and Mohr, I. (2006) Assembly of an active translation initiation factor complex by a viral protein. Genes Dev. 20, 461-472.

Wang, H., Buckley, K.J., Yang, X., Buchmann, R.C. and Bisaro, D.M. (2005) Adenosine kinase inhibition and suppression of RNA silencing by geminivirus AL2 and L2 proteins. J. Virol. 79, 7410-7418.

Wang, M.B., Masuta, C., Smith, N.A. and Shimura, H. (2012) RNA silencing and plant viral diseases. Mol. Plant-Microbe Interact. 25, 1275-1285.

Ward, B.M. and Lazarowitz, S.G. (1999) Nuclear export in plants: use of geminivirus movement proteins for a cell-based export assay. Plant Cell, 11, 1267-1276.

Ward, B.M., Medville, R., Lazarowitz, S.G. and Turgeon, R. (1997) The geminivirus BL1 movement protein is associated with endoplasmic reticulum-derived tubules in developing phloem cells. J. Virol. 71, 3726-3733.

Wartig, L., Kheyr-Pour, A., Noris, E., De Kouchkovsky, F., Jouanneau, F., Gronenborn, B. and Jupin, I. (1997) Genetic analysis of the monopartite tomato yellow leaf curl geminivirus: roles of V1, V2, and C2 ORFs in viral pathogenesis. Virology, 228, 132-140.
Weisshart, K., Taneja, P. and Fanning, E. (1998) T antigen and its role in the initial steps of SV40 DNA replication. J. Virol. 72, 9771-9781.

Wimmer, P., Schreiner, S. and Dobner, T. (2012) Human pathogens and the host cell SUMOylation system. J. Virol. 86, 642-654.

Wright, E.A., Heckel, T., Groenendijk, J., Davies, J.W. and Boulton, M.I. (1997) Splicing features in Maize streak virus virion- and complementary-sense gene expression. Plant J. 12, 1285-1297.

Xie, Q., Suarez-Lopez, P. and Gutierrez, C. (1995) Identification and analysis of a retinoblastoma binding motif in the replication protein of a plant DNA virus: requirement for efficient viral DNA replication. EMBO J. 14, 4073-4082.

Xie, Q., Sanz-Burgos, A.P., Hannon, G.J. and Gutierrez, C. (1996) Plant cells contain a novel member of the retinoblastoma family of growth regulatory proteins. $E M B O \mathrm{~J}$. $15,4900-4908$

Xie, Q., Sanz-Burgos, A.P., Guo, H., Garcia, J.A. and Gutierrez, C. (1999) GRAB proteins, novel members of the NAC domain family, isolated by their interaction with a geminivirus protein. Plant Mol. Biol. 39, 647-656.

Yaakov, N., Levy, Y., Belausov, E., Gaba, V., Lapidot, M. and Gafni, Y. (2011) Effect of a single amino acid substitution in the NLS domain of Tomato yellow leaf curl virus-Israel (TYLCV-IL) capsid protein (CP) on its activity and on the virus life cycle. Virus Res. 158, 8-11

Yang, L.P., Fang, Y.Y., An, C.P., Dong, L., Zhang, Z.H., Chen, H., Xie, Q. and Guo, H.S. (2012) C2-mediated decrease in DNA methylation, accumulation of siRNAs, and increase in expression for genes involved in defense pathways in plants infected with beet severe curly top virus. Plant J. 73, 910-917.

Yang, X., Baliji, S., Buchmann, R.C., Wang, H., Lindbo, J.A., Sunter, G. and Bisaro, D.M. (2007) Functional modulation of the geminivirus AL2 transcription factor and silencing suppressor by self- interaction. J. Virol. 81, 11972-11981.

Yang, X., Xie, Y., Raja, P., Li, S., Wolf, J.N., Shen, Q., Bisaro, D.M. and Zhou, X. (2012) Suppression of methylation-mediated transcriptional gene silencing by $\mathrm{BC} 1-\mathrm{SAHH}$ protein interaction during geminivirus-betasatellite infection. PLoS Pathog. 7, e1002329.

Zhang, D., Frappier, L., Gibbs, E., Hurwitz, J. and O'Donnell, M. (1998) Human RPA (hSSB) interacts with EBNA1, the latent origin binding protein of Epstein-Barr virus. Nucleic Acids Res. 26, 631-663.

Zhang, S.C., Wege, C. and Jeske, H. (2001) Movement proteins (BC1 and BV1) of Abutilon mosaic geminivirus are cotransported in and between cells of sink but not of source leaves as detected by green fluorescent protein tagging. Virology, 290, 249-260.

Zhang, S.C., Ghosh, R. and Jeske, H. (2002) Subcellular targeting domains of Abutilon mosaic geminivirus movement protein BC1. Arch. Virol. 147, 2349-2363.

Zhang, W., Olson, N.H., Baker, T.S., Faulkner, L., Agbandje-McKenna, M., Boulton, M.I., Davies, J.W. and McKenna, R. (2001) Structure of the Maize streak virus geminate particle. Virology, 279, 471-477.

Zhou, Y., Rojas, M.R., Park, M.R., Seo, Y.S., Lucas, W.J. and Gilbertson, R.L. (2011) Histone $\mathrm{H} 3$ interacts and colocalizes with the nuclear shuttle protein and the movement protein of a geminivirus. J. Virol. 85, 11821-11832.

Zhou, Y.C., Garrido-Ramirez, E.R., Sudarshana, M.R., Yendluri, S. and Gilbertson, R.L. (2007) The N-terminus of the Begomovirus nuclear shuttle protein (BV1) deter mines virulence or avirulence in Phaseolus vulgaris. Mol. Plant-Microbe Interact. 20, $1523-1534$

Zu, Y.L., Takamatsu, Y., Zhao, M.J., Maekawa, T., Handa, H. and Ishii, S. (1992) Transcriptional regulation by a point mutant of adenovirus-2 E1a product lacking DNA binding activity. J. Biol. Chem. 267, 20 181-20 187. 